\title{
Adriaan Reland: A Life in Fragments
}

\author{
Anna Pytlowany
}

\section{Introduction}

In the spring of 1711, the young German bibliophile Zacharias Conrad von Uffenbach (1683-1734), accompanied by his brother Johann Friedrich, travelled through the Dutch Republic visiting famous collectors and libraries. ${ }^{1}$ On the morning of April 2nd, they went to visit Professor Adriaan Reland at his home in Domsteeg in Utrecht. 'The professor, not much more than thirty years old', Uffenbach noted in his diaries, was 'polite and well-disposed, but he did not restrain himself once he opened his mouth'. ${ }^{2}$ Reland apparently made no attempt to dazzle the brothers with his scholarly expertise since they remarked that 'he belongs to those who are not terribly concerned about being pedantic'. 'Mr. Reland spoke of all sorts of learned things', including the valuation of certain Hebrew manuscripts from the collection of his recently deceased colleague, the Danish scholar and polyhistor Marcus Meiboom (1626-1711), whose widow the brothers went to see the same afternoon, and some lighter issues like the worrisome marriage of the latter's daughter. ${ }^{3}$ When Uffenbach asked if there were other connoisseurs among the university professors who owned libraries or cabinets, Reland denied it and added in a strange fashion: 'what is the advantage of having a large number of books?' He must have been

1 I would like to thank Bart Jaski, Henk van Rinsum, and Christian Lange for their valuable comments on the first draft of this paper, Áine Sheehan for inspiring historical discussions, and Fearghal Duffy who helped me immensly with my English.

2 Uffenbach, Merkwürdige Reisen (1754), pp. 704-705.

3 In the same year, Reland edited Meiboom's translation of Epictetus (Epicteti Manuale et Sententiae): 'The Publick is very much indebted to M. Reland for this New Edition of Epictetus, which perhaps would have been laid aside after the Death of M. Meibomius, had not that Learned Professor taken care to go on with it, and to put in order the Notes of M. Meibomius, that were dispersed in the Margins of several Books, and in many loose Papers'. (Memoirs of Literature, pp. 12-13). In line with his general approach, Reland also purged the text from inserted Christian elements: '[M. Reland] has extracted many various Readings out of a MS of Epictetus, which has been interpolated in several Places to make it agree with the Christian Doctrine. The word God does frequently appear in that Manuscript instead of gods in the Plural Number; and sometimes Paul (the Apostle of that name) instead of Socrates. Such a pious Fraud is more excusable than several others'; ibid., p. 13. 
a bit uneasy about the visit, as he declared that he never showed his library to anyone because 'there were papers lying around'. However, he offered to show them some fine Oriental manuscripts which he wanted to bequeath to the university. Indeed, he returned with six items, one of which was a precious clean and neatly drafted 'Persian Genealogy'. ${ }^{4}$ He also mentioned a beautiful unpublished Arabic Lexicon of Thomas Erpenius, ${ }^{5}$ but did not show it to them, and since he behaved with such poise and detachment, the brothers did not like to ask for it. Little did Reland know that in a few years' time, Uffenbach would become famous as the owner of the largest book collection on the continent, and Reland's own 'papers and manuscripts' would end up scattered between libraries and archives across Europe. ${ }^{6}$

Uffenbach's account offers one of the rare glimpses into Adriaan Reland's private life and personality. The Utrecht scholar died suddenly seven years later, leaving a wealth of published scholarly material — but not many personal notes or letters. The majority of his library was auctioned in November 1718, yet the manuscript collection was not passed on to the University, as he had wished, but stayed in the family until the death of Reland's son Jan Hubertus in 1761. The auction catalogue from that year ${ }^{7}$ contains an index of manuscripts, mostly of a linguistic nature, which allow us to see what 'exotic' languages Reland had access to, and who provided him with material for his comparative linguistic work. The catalogue answers some questions about his linguistic lineage, since several Oriental manuscripts came from Golius, Erpenius, and other Orientalists, and about provenance too, because some titles mention Reland's informants overseas. Besides the manuscripts, the catalogue lists other sundry items: ancient inscriptions; antique and Oriental coins; shells and other naturalia; and even an inventory of scientific instruments and gadgets. Since some of them are possible to date, they offer a chance to revisit Reland's wide range of interests and sometimes unexpected sources of inspiration. Whatever else we can reconstruct of Reland's life, his contacts

4 Arnoud Vrolijk suspects it was 'TAARICH sive Genealogia ab Adamo usque ad Sultan Morad ... ex Persico in Turcicum sermonem translata ... ex Biblioth. Golii' mentioned in Reland's catalogue from 1761; see Appendix 2, A qua 17, in this volume.

5 This is now Leiden, University Library, Or. 1649; see Appendix 2, A fol 6, in this volume.

6 The task to establish where these manuscripts are today and how they got there is still ongoing (see the chapters of Bart Jaski and Arnoud Vrolijk in this volume), as is the question of if and how Reland actually used them in his work. An exploratory overview entitled 'Tracing origin and reuse of lexical material in the works of Adriaan Reland (1676-1718)' was presented by Anna Pytlowany and Rebeca Fernández Rodríguez at the 1oth International Conference on Historical Lexicography and Lexicology (ICHLL-10), Leeuwarden, 14 June 2019.

7 Naam-lyst van een zeer keurige verzameling [...] boeken. [...] [\&] Catalogus codicum manuscriptorum Arabicorum (1761). See Appendix 2 in this volume. 
and his friendships, is mostly based on letters and other archival fragments mainly found in the libraries in The Netherlands, Germany, and England. The remaining tangible pieces of Reland's less formal legacy take the form of book dedications (to him and by him), inscriptions in alba amicorum, as well as commemorative poems he wrote for his colleagues' works-and vice-versa. ${ }^{8}$ I will present these miscellanea in the context of the cultural and intellectual climate of Utrecht around 1700, as I attempt to track and sketch Reland's social and scholarly network.

Reland's fascination with scientific experiments was already clearly visible in his Leiden years. ${ }^{9}$ It was a time when earlier humanistic and medieval scholastic ideas of natural philosophy were a thing of the past, and 'a (neo-) Aristotelian world view that was gradually crumbling..10 In the spirit of Francis Bacon (1561-1626) and Robert Boyle (1627-1691), young Reland joined the classes of proefondervindelijke wijsbegeerte (experimental natural philosophy) with one of its founders in Leiden, Wolferd Senguerd (1646-1724). True to the British Royal Society's motto Nullius in verba, 'take nobody's word for it', he sought to use his own senses there to 'discover fundamental facts about nature.'11 In 1694 Reland's defended his thesis Exercitationis physico mathematica De umbra pars prior ('Of shadow'). P. Marcus, a student of philosophy, wrote a dedicatory poem for his friend: ${ }^{12}$

8 See also Appendix 5 with the commemorative poem in Arabic by Heinrich Sike from 1696 on the occasion of Reland's disputation about the similarities between Islam and Judaism.

9 See Henk van Rinsum's chapter in this volume.

10 Ibid.

11 Berkowitz, 'Pumped Up' [web blog].

12 Interestingly, both dissertations were written under professor Jan Luyts (1655-1721), a rather conservative and anti-Cartesian Dutch physicist, mathematician, and astronomer, also known for his extensive book on world geography Introductio ad geographiam novam et veterem (published by Halma in 1692) that included the Old and the New World, and he added material on the East Indies and America to Herman Moll's A System of Geography; or, A New and Accurate Description of the Earth in All its Empires, Kingdoms and States. Illustrated with History and Topography, and Maps of Every Country (1701). At the time, 'Dutch volumes of geography were the standard setting, sought after sources for the exotic world' (Schmidt, Inventing Exoticism, p. 28). Did Reland's initial interest in cartography come from Luyts, and later get enriched by his studies of Asian languages? On Reland's methodology of combining maps with further research on the topic using indigenous sources, see Tobias Winnerling's chapter in this volume. 
[...] Here a clever brain enlightened by education finds

The reason of, and can just explain the cause:

The shadow teaches the height, and depth of mountain and valley,

Of tops of towers, the course of the sun, and of moonlight

And shows how the Earth is not square, but like a ball

Hangs in the middle, as shown by solar eclipse.

This and other use the shadow teaching gives us:

Why it is necessary, to understand the cases,

Already a disputed examination, what truth or falsehood gives,

So that one may strike the target of true wisdom.

This gave proper material for Reland's clever orations

That were disputed to everyone's full delight

Thoughts and mind's differences of one:

There's no doubt he will carry fame away once again. ${ }^{13}$

Reland's scientific adventure lasted a couple of years, during which he got acquainted with the most recent scientific instruments. After all, Leiden was the first university in Europe to establish in 1674 a theatrum physicum, and the inventory from 1705 shows that the Leiden Cabinet of Physics contained 64 instruments for experiments with magnetism, mechanics, and optics. ${ }^{14}$ At the time, the air pump or vacuum chamber was much in vogue. It was used to demonstrate the properties of air including its pressure, or 'spring of the air'. In 1696 Reland's friend and colleague Gijsbert van Leeuwen defended a thesis on Toricelli's experiment with a mercury-filled tube which demonstrated the existence of a vacuum and linked it with the atmospheric pressure. ${ }^{15}$ Reland wrote an introductory poem De vacuo ('On vacuum') for inclusion in van

13 Transcription and translation from Dutch by Kees Huyser (the original italicisation ommited in English).'[...] Hier vint een schrander breyn door onderwijs verlicht /De reden van, en kan ons d'oorzaak net verklaaren:/ De Schaduw' leert de hoogt, en diept van berg en dal,/ Van Toorens top, der Sonnen-koers, en Maneschijnen, /En toont hoe d'Aard niet vierkant is, maar als een bal/ Hangt in het middelpunt, by Son-Eclips verschijnen.

Dees en meer ander nut de Schaduw-leer ons geeft/ Waarom wel noodigh is, tot saaken wel beseffen,/ Reed'-twistight-ondersoek, wat waar of valsheit geeft,/ Op dat men 't doelwit moogt van waare wijsheit treffen./ Dit gaf een regte stof voor Reelands schrand're Reen/ Die onlangs heeft betwist tot ieders vol behaagen/ Gedachten en gemoeds verschilligheid van een:/ Geen twijffel of Hy sal de Roem ook nu wegdraagen.'

14 De Clercq, At the Sign of the Oriental Lamp, p. 139.

15 Leeuwen and Luyts, Exercitatio physica de vacuo (1696). The transcription below is based on Reland's manuscript of the poem from The Hague, Royal Library, 121 E 5 . 
Leeuwen's thesis. In his enthusiasm for his friend's subject, Reland could not help demonstrating his own mastery of Latin:

de vacuo

egregiter disputante

Primo vere tumentia

Laeti conspicimus germina, divitis

quae nos spe segetis fovent,

venturi quoniam temporis exitum

rerum exordia praemonent.

Mentis nobilitas, ingenium et vigor

primiis in studiis micant.

Hinc spes non dubio (dum specimen paras, annis in juvenilibus

naturae penetrans, qua licet, abdita)

pascit nos ea gaudio

te, qui conspicuo Palladis in foro

motis litibus imperas,

tandem ad sollicitae commoda patriae

tollendum fore celsius,

ut docto ferias nubila vertice

vulgares super orbitas.

Ergo te stabiles laudis adoreae,

te stipata perennibus

laurorum cumulis lustra, beent diu!

ADR. RELAND ${ }^{16}$

The more abstract approach and his poetic style distinguish it from the somewhat pedestrian verses produced by his peers. Apparently, Reland's scientific mind neither hindered nor overshadowed his poetic sensibilities.

16 Transcription and the English translation by Josef Eskhult: 'In the early spring we gladly see the swelling buds that favour us with a hope of a rich harvest/ since the beginning of events foretell the outcome of the future time./ The nobility, talent and strength of your mind are brightening in your first studies./ Hence, without a doubt hope nourishes us (when you in young years provide proofs that penetrate into the secret places of nature, as far as it is possible). It nourishes us with the joy/ that you, who in the conspicuous public place of wisdom rules the emerged controversies, finally will be raised higher to the benefit of the troubled fatherland, so that you attain with the clouds the learned top above the common orbits./ Accordingly, may the stable glories of praise and periods filled with continuous heaps of laurels make you happy for a long time!' 
Nevertheless, the reputation of Leiden as 'a centre from which the new development emanated to the other universities' helped to fast-track its former students to appointments to chairs of philosophy in the other three important Dutch universities. ${ }^{17}$ That was probably how Reland's first academic appointment as Professor of Physics and Metaphysics at Academia Gelro-Zutphanica in Harderwijk came about.

Considering Reland's early scientific proclivities, it is quite thrilling to see that Jan Hubertus' auction catalogue (1761) contains a list of technical instruments ('Instrumenten Tot de Natuur-Gezicht- en Tuigwerk-kunde, en andere Wetenschappen behoorende'), serving to demonstrate natural, optical, and mechanical phenomena: various microscopes, telescopes, and even an air pump. ${ }^{18}$ However, the production dates on some of the instruments preclude that Reland was the owner, since they were manufactured after his death: five items come from Jacob Huysen (1739-1792), an instrument maker in Utrecht; one extra fraije Telescoop, door van de Bilt, a reflecting telescope, was made by Johannes van der Bildt Jansz (1736-1780), a well-known Frisian telescope maker. A Zonnemicroscoop, solar microscope, a type of projector using sunlight to illuminate the microscopic preparations and casting them strongly magnified onto a wall, is also from the mid-eighteenth century. A draaibank (a lathe), was used for experiments with electricity, and suggests that its owner was performing experiments in this field.

But why would Jan Hubertus, a magistrate and counsellor of the small city of Zierikzee, invest in a pile of scientific instruments? According to Zuidervaart, the reasons lie in the zeitgeist. After the 1714 reprint of Newton's Philosophiae naturalis principia mathematica in Amsterdam with an additional essay, Scholium generale (English: General Scholium), in which Newton professed his belief in God as the governing force behind the laws of nature, 'a wave of popularisation of 'Newtonian' philosophy went through the Dutch Republic':

Where previously collectors have focused on bringing together natural history specimens and artificialia, ${ }^{19}$ now a new form of collecting emerged: the 'cabinet of experimental philosophy'. Wealthy merchants,

\footnotetext{
17 De Clercq, At the Sign of the Oriental Lamp, p. 135.

18 Since Reland's children were still minors at the time of his death a probate inventory should have been made. After all, a similar situation occurred when Anthony van Leeuwenhoek (1632-1723) died, leaving his entire instrument collection to his daughter Maria in the will that was not probated until twenty years later, after her death (Anderson, D., Lens on Leeuwenhoek [website]).

19 Bergvelt et al. (eds.), Kabinetten, galerijen en musea, pp. 15-68, 101-128. See also Roemer, 'Neat Nature', pp. 47-84.
} 
bankers and other enthusiasts, especially in the urbanized part of the country, started to build such an instrument collection, often as an extension of their library. ${ }^{20}$

Such collections were a signifier of social status, as well as provided entertainment. ${ }^{21}$ Anyhow, the line between enthusiast and academic scientist was vague at the time, with many individuals of privileged backgrounds engaging in scientific research and discovery outside of academia. Having said that, since Reland's first academic appointment was as Professor of Physics and Metaphysics, and since a professor of natural philosophy was expected to provide the scientific instruments he needed for his courses, it is not unreasonable to assume that some of the instruments originally did belong to him, and not to his son. The question is whether Reland, who had only been in the post for eight months, would have had enough time (and earnings) to acquire any of them. ${ }^{22}$ For instance, de Clerq estimates that there were only one or two air pumps made per year, ${ }^{23}$ and the prices for the best models reached $500-600$ guilders, 'half a year's salary for a university professor!' 24 The air pump in the catalogue came from the famous Van Musschenbroek workshop, which supplied the Dutch universities as well as selling abroad to Germany, Russia, and Italy, and seems to date to the turn of the eighteenth century. Although these instruments were made up to the death of Jan van Musschenbroek (1687-1748), this cheaper horizontal (leggende) model was rather outdated by the time the catalogue was compiled in 1761 , and sold for 40 guilders. ${ }^{25}$ The only other instrument on the list that seems to date from around 1700 (or even earlier) is the small, one foot long ${ }^{26}$ Blikke verrekyker, an iron-plated telescope. ${ }^{27}$ Since the catalogue also mentions Zes kopere Bekkentjes om glaasen in te slijpen ('six copper bowls to cut glass'), it is possible that Reland ground his own lenses when fixing or replacing broken ones in the telescope.

But there is also a dateless, playful side to the collection: a number of gadgets such as the Tantalus cup (also known as the Pythagorean 'greedy cup',

20 Zuidervaart, 'Cabinets for Experimental Philosophy in the Netherlands', pp. 5-6.

21 Ibid. p. 6.

22 By 1700 , the University of Harderwijk already had its own air pump, even though 'that university did apparently not see proper physics demonstration before 1735' (De Clercq, At the Sign of the Oriental Lamp, p. 135).

23 Ibid. pp. 175-179.

24 Ibid. p. 107.

25 I owe this observation to Rienk Vermij.

$26 \quad 1$ foot $=30.48 \mathrm{~cm}$.

27 For an in-depth overview of seventeenth-century Dutch and European telescopes, see Zuidervaart, 'The "Invisible Technician" Made Visible'. 
a normal-looking cup that empties itself through a siphoning effect when it is filled beyond a certain level); a pressure-driven hydraulic machine called Heron's fountain; seven 'Cartesian devils' (Carthesiaanse Duyveltjes), small devil-shaped figurines floating and sinking in a bottle of water with a membrane on top, used to demonstrate Archimedes' principle of buoyancy; two camerae obscurae; a magic lantern with 59 objects, seven of which move. Last but not least, there is a serinette, a small barrel organ used to teach canaries to sing. Whether it was the father or the son who enjoyed them, it is heartwarming to note that the passion for the sciences was passed on from Reland to his son. Both auction catalogues (1718 and 1764$)$ contain volumes of works on the natural sciences. Yet, while Reland was studying heavyweight works like Boyle's Opera, Galileo's De systemate Mundi and Mechanica, Jacques Rohault's Physica and De arte mechanica tractatus, de Mey's Commentaria physica; Luyts' Astronomica institutio; Senguerdius' Inquisitiones experimentales and Philosophia naturalis; Sturm's Physica electiva; Huygens' Systema Saturnium; Salignac's Arithmeticae et algebrae, etc., his son relied on school books such as Herman Boerhave's Elementa chemiae (1732) or Jacob Ode's Principia philosophiae naturalis (1727). It is clear that though Reland and his son were not full-time scientists, they did their best to stay up to date with contemporary scientific thought and practice.

Reland's Harderwijk episode did not last for even a year. According to the anonymous author of the note in the Journal Literaire, ${ }^{28}$

Above all, he loved peace and tranquillity, and that is the main reason why he gladly quit the professorship of Philosophy, in which, if one wants to think and speak freely, one instantly exposes oneself to quibbling and the hatred of raisonneurs by profession. ${ }^{29}$

But 'the wonderous study of Nature never ceased to be one of his favourite occupations; to perfect it, he attached himself to the new method that allows

28 The article on Reland's death in the Journal Literaire (vol. 10, part 2, 1720, p. 216) is very similar to Reland's funeral oration by Serrurier, which suggests that it may have been written by Serrurier as well. Both this article and the Oratio funebris were quoted again by Chauffepié in his Nouveau dictionnaire historique et critique, vol. 4, p. 93.

29 'Aussi aimoit-il sur toutes choses la paix et la tranquilité, \& c'est une de plus fortes raisons qui le portérent à quitter avec plaisir le Professorat de la Philosophie, dans lequel si l'on veut penser \& parler librement, on s'expose à coup sur aux ergoteries, \& à la haine des Raisonneurs de profession', Chauffepié, Nouveau dictionnaire historique et critique, vol. 4, p. 93 . 
only physical reality which is discovered by experiments, ${ }^{30}$ concluded the anonymous author. Collecting evidence-be it specimens of unknown writing systems, ancient inscriptions, or 'exotic' coins-became henceforth the driving force of Reland's research methodology.

\section{Reland the Expert}

\subsection{Numismatics}

Long before Reland's love for antiquities and a keen knowledge of 'exotic' languages gained him recognition and popularity in learned circles at home and abroad, his career choices were probably inspired by some consequential adolescent encounters. One of Reland's life-long interests was numismatics, and his fascination with coins can be traced back to his youth, when he was acquainted with the famous Amsterdammer Jacob de Wilde (1645-1721). Besides holding a high-ranking function in the Admiralty of Amsterdam, De Wilde was one of the most renowned coin experts in the Dutch Republic. His collection, which included medals as well as ancient statues and scientific instruments, was housed in the Museum Wildeanum built behind his property on Keizersgracht 333 in Amsterdam, where in 1697 he received a famous visit from Czar Peter the Great (who may have acquired the collection after De Wilde's death in 1721). In 1694, when Reland was barely 18, De Wilde presented him with his book Selecta numismata antiqua dedicating it 'to the excellent student Adriaan Reland, as a token of friendship' [Fig. 10.1]. ${ }^{31}$

It is unclear how the friendship between Reland and De Wilde started. Was Reland just a visitor to the Museum before he became De Wilde's protégé? In any case, in 1700 Reland wrote a Latin accolade for De Wilde's daughter Maria, to be included in the catalogue Signa antiqua e museo Jacobi de Wilde [Ancient statues from the museum of Jacob the Wilde], for which Maria had produced the engravings. ${ }^{32}$ It is clear that Reland was close enough to the De Wilde family to write quite intimately about Maria's work. Below is one fragment, in which Reland concludes that 'the marbles soften under the touch of the beautiful girl', and 'happy is the one who her right hand embraces; she gives life to

30 'Létude admirable de la Nature ne laissoit pas d'être toujours une de ses occupations chéries; pour s'y perfectionner il s'attachoit à la nouvelle méthode, qui n'admet que de vérités Physiques, qu'on découvre par les Expériences', ibid. p. 93.

31 'Praestantissimo studioso HRelandio in tesseram amicitae D.D. [Dono Dedit]....'

32 The poem is on pp. B 8-9. On Maria and other liminary poems for her, see Jan Just Witkam's chapter in this volume. 


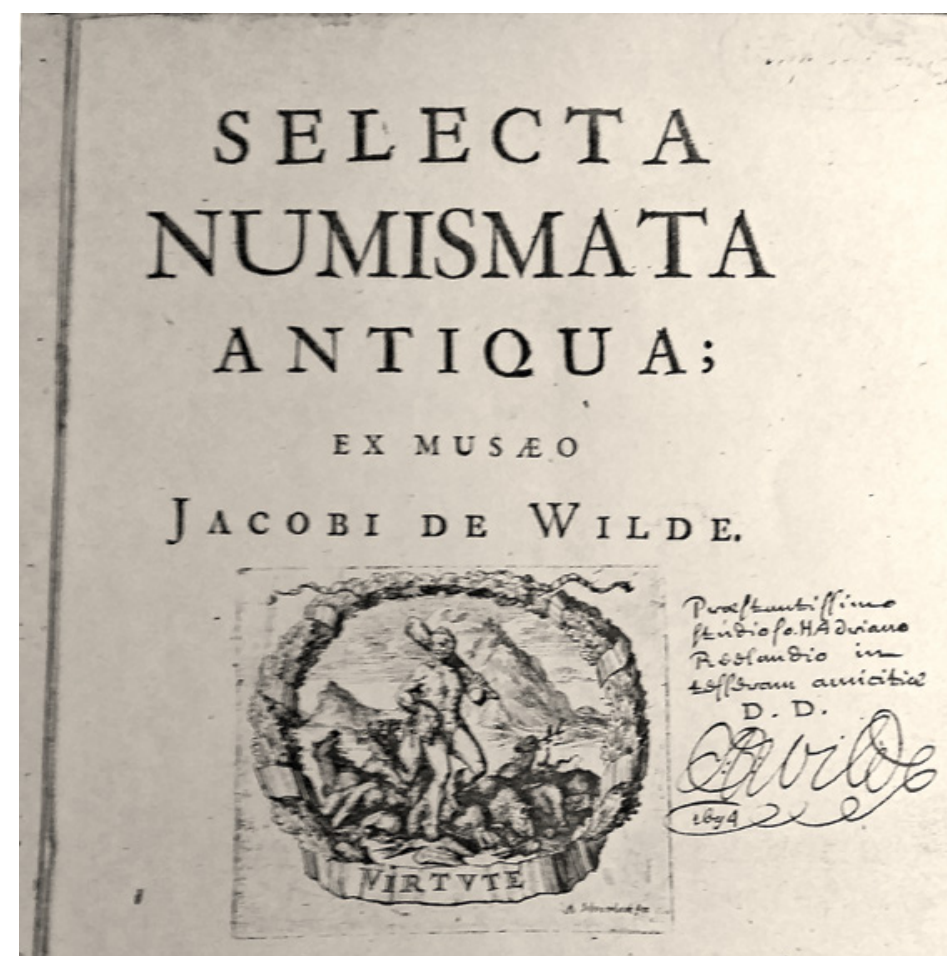

A M S T E L OD A M I,

Sumptibas Authoris. cio IOC I XXXXII.

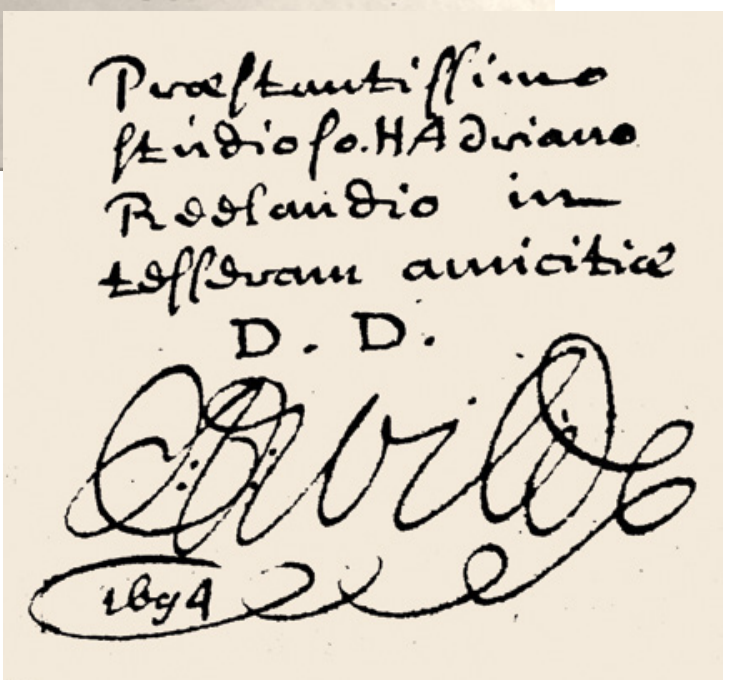

FIGURE 10.1 Dedication to Reland by De Wilde, in Selecta numismata antiqua, 1694 IMAGES COURTESY OF HUIB ZUIDERVAART 
marble sculptures', and they in turn 'give her life' - presumably the eternal life of fame:

\author{
Credible est, ea dum tangis, Pulcherrima virgo, \\ Marmora contactu mollia facta Tuo. \\ Felicem, talis quem dextera complectetur: \\ Candida, perpetuâ dextra colenda fide. \\ Evolat, \& coelo Tibi fama acclamat aperto: \\ Marmoribus vitam Tu dabis, illa Tibi.
}

Soon, he became a recognised expert in antiquities and ancient languages in his own right. In 1702 and 1704, Reland published two parts of his book on Samaritan (i.e. Hebrew) coin inscriptions and dedicated both to De Wilde. ${ }^{33}$ Like De Wilde, he was consulted about pieces of exotic or ancient origin. One of them was a gold coin found on the lands of Count Kniphuisen near Utrecht. ${ }^{34}$ In the Lettre à son excellence monseigneur le comte de Kniphuisen ... sur une pièce d'or trouvée dans ses terres (1713) - a rare case of a letter written in French-Reland contested the previous expertise by Martin Schookius who classified the coin as probably being Gothic (the characters resembled Danish), and presents arguments for its mediaeval Merovingian origin. On pages 8-10 of his letter, in a display of understanding of local geography, Reland argues that the place where the coins were minted (TRIECTO FIT; or TRIECTO VICO), was Utrecht (near where it was found) rather than the generally accepted Maastricht. ${ }^{35}$

Reland not only studied other people's coins but also liked to collect them himself, and his interest knew no geographical bounds, probably thanks to his voc network. ${ }^{36}$ Jan Hubertus' auction catalogue contains two lists: a collection

33 Reland, Dissertatio De inscriptione nummorum quorundam Samaritanorum, vol. 1 (1702), and Dissertatio altera De inscriptione nummorum quorundam Samaritanorum, ad spectatissimum virum, Jacobum de Wilde (1704).

34 Kniphuysen was a diplomat and a plenipotentiary at the Peace of Utrecht negotiations in 1713, in which Spain gave Britain the slave trade contact known as the Asiento, and ceded the port of Gibraltar to them.

35 The argument is based on the fact that Reland had seen another coin made by a mint master by the same name, MADELINVS, and minted in Dorestat. Until the twelfth century Utrecht was called Vicus subtus Dorestatum (or 'the Village by Dorestat', near today's Wijk bij Duurstede, as opposed to Maastricht, which was called Urbs, a city, long before). The village across the river from Maastricht was called Wyck (now a part of Maastricht), which, according to Reland, led some people (i.e. 'Messieurs de Valois \& Mabillon') to the erroneous conclusion that Trajectus Vicus must be Maastricht.

36 However, Reland's interpretations were not always quite accurate, as can be seen in the case of seal No. 6 discussed in this volume by Witkam ('§ 9. On the seals of private persons, 
of twenty four 'Oriental Coins' (Numii Orientales), and ten ancient Roman coins (Numii antiqui Romani). Among the Oriental ones, we find a Tang, or Aracans rupee; ${ }^{37}$ two silver rupees (duae rupiae argenteae nec non dimidia); three Persian coins called Abbassi; ${ }^{38}$ two coins from Ceylon called Laryns; ${ }^{39}$ silver coins from Isfahan; 'a small gold Egyptian coin called Parra(s)'; a gold coin from the Island (sic) of Coromandel dictus fanem de Tritsenapilla; similar coins from Tutocorin; gold Punic coins (probably from North Africa); two coins from the area of 'Tipora en Ansem'; a golden coin from the Kingdom of Bantam called Pitty; ${ }^{40}$ two coins of the same kind from the Island of Java but with 'Chinese letters'. The next five items are jointly marked as ex aere ('from bronze'). The note specifies that at least three of them were described by the clarissimi defuncti in his works De nummis Samaritanis, for which exact page references are provided. ${ }^{41}$ The second list describes ten ancient silver and gold Roman coins. Last but not least, various commemorative brass medals from Holland are mentioned. Some of these coins depicted in the auction catalogue were probably drawings made by Reland himself [Fig. 10.2 and 10.3].

and on the seal of the Turkish emperor'). According to Mitresh Singh, an Indian scholar and numismatist, the correct reading is 'Narso Pandit 1077 Ibn Kesho Pandit'. The date falls within the reign of the Mughal Emperor Aurangzeb. Reland's association of the two names with names of rivers is incorrect, and the translation of the inscription is 'Narso Pandit (son of) Kesho Pandit'. The seal is simply a private seal of a learned man with a certain social status (Mitresh Singh, personal communication).

37 The historical kingdom of Arakan, near the eastern coast of the Bay of Bengal (roughly corresponding to Rakhine State in Myanmar today). Wouter Schouten (1638-1704), who spent four months there in 166o, says that 'the smallest silver pieces used on Arracan are a Tang, or Moorish Rupee, which is 25 stuyvers in Dutch money'; see Schouten, Oost-Indische voyagie (1676), p. 156.

38 The 'Abbāsī is a silver coin first issued by the Safavid ruler of Iran Shāh 'Abbās I (reigned AH 995-1038 / CE 1587-1629), 'which dominated Iranian coinage until the middle of the twelfth/eighteenth century', see Floor, 'Abbāsī', in Encyclopaedia of Islam, THREE [website]. For silver coins, until the end of the Safavid period, the 'abbāsī equaled to 200 dinars; see Matthee, Persia in Crisis, p. 77.

39 'The most current Coin here are the Silver Laryns, each whereof is worth about 1od'; see Baldaeus, A True and Exact Description of the Most Celebrated East-India Coasts, p. 822.

40 According to Glanius, Bantam currency 'which in the Malayan (sic) language is called Cus, in the Bantam Tongue Pitty' was made in the Chinese town of Chincoa, brought to Bantam with the China fleet, and was 'current not only at Bantam, and all the Isle of Java, but through all the Neighbouring Islands. 'Tis a little thin Plate made of Lead, and the scum of Brass, so brittle that letting fall a string of Caxaes [coins], you shall break at least ten or twelve'; see Glanius, A New Voyage to the East-Indies, p. 71.

41 They are collected in De Nummis veterum Hebraeorum ... Dissertationes quinque (1709), dedicated to De Wilde. 


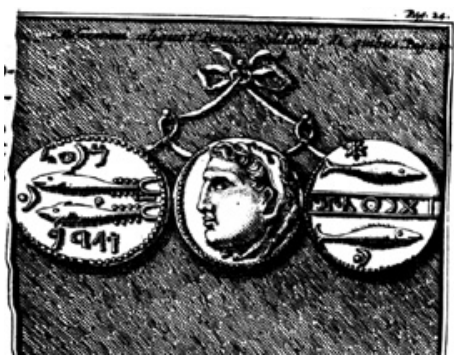

FIGURE 10.2

The Roman coin featuring a head wearing a lion's scalp, and two fish (drawing by Adriaan Reland, Dissertatio De inscriptione nummorum quorundam Samaritanorum, 1702: 24)
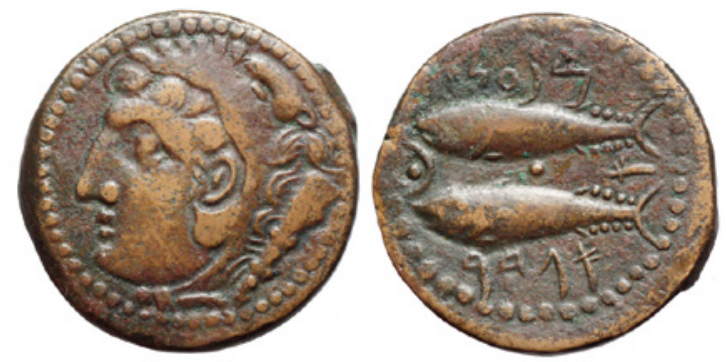

FIGURE 10.3 The likely original: a 2nd-century вС coin from Cádiz, Spain, with head of Herakles wearing a lion's skin (obverse), two tunny fish and Punic script (reverse). COURTESY ROMA NUMISMATICS LTD, WWW.ROMANUMISMATICS.COM

\subsection{Networking}

Reland's interest in ancient coins and their inscriptions brought him into contact with Gisbert Cuper (1644-1716), the antiquarian, philologist, burgomaster of Deventer, and once professor of history and eloquence at the Deventer Athenaeum. Like De Wilde, he was significantly older than Reland, and he had been very successful, to use Chen's words, at 'connect[ing] knowledge and power. 42 Cuper used his political positions to acquire 'objects and information' from multiple sources to help satisfy his quest for knowledge. Because of his double position as scholar and politician Cuper 'could lend an aspiring scholar power and knowledge, or even better, reward his protégé with entry into his network of trans-European scholars. ${ }^{43}$ And indeed, if we compare the epistolary networks of Cuper and Reland, we find many of the same names.

42 Chen, 'Digging for Antiquities', p. 3. See also Peters, 'Nicolaes Witsen and Gijsbert Cuper'.

43 Chen, 'Digging for Antiquities', p. 4. 
Besides, the letters to and from Cuper form the largest part of Reland's preserved correspondence.

Cuper may have been instrumental in instigating at least some of these contacts; we do know that he initially served as a go-between between Reland and Nicolaes Witsen (1641-1717), the longstanding burgomaster of Amsterdam and one of the seventeen directors of the Dutch East India Company (voc). For example, in 1704, Witsen received a very special gift from a Russian friend: a round metal mirror found in a grave in Siberia, inscribed with 'seemingly ancient yet inscrutable characters' ${ }^{44} \mathrm{He}$ discussed it at length in his correspondence with Cuper, as they wanted to crack the code of the mysterious, ostensibly Chinese, inscription. Although the mirror itself got shattered as a result of Witsen's accidentally dropping it, an engraving had already been made and published in a revised edition of his book Noord en Oost Tartarye [North and East Tartary] by Halma in Amsterdam in 1705. Additionally, copies of the image were sent to several learned men of Europe, voc officials in touch with Chinese communities in Batavia, as well as missionaries in China and India. Alongside such eminent European scholars as the German polymath Gottfried Wilhelm Leibniz (1646-1716), the French statesman and member of the Académie française Jean-Paul Bignon (1662-1743), and the French historian and Orientalist Mathurin Veyssière La Croze (1661-1739), Reland also received a copy via Cuper. He in turn consulted a Frenchman, a certain Mr. Masson, ${ }^{45}$ who was helping him with translating Chinese and Japanese manuscripts from his collection. ${ }^{46}$

Allegedly Reland had even more direct encounters with foreign informants. According to the second-hand account from $1711,{ }^{47}$ Reland was at the time collaborating directly with a certain Hottentot brought to Holland, presumably as a slave. With his help, the professor was hoping to produce a grammar

44 Van Noord and Weststeijn, 'The Global Trajectory of Nicolaes Witsen's Chinese Mirror', p. 325 .

45 Philippe Masson (life dates unknown) was a minister at the Walloon Church (Kuiper, 'The Earliest Monument of Dutch Sinological Studies', p. 114). Reland to Cuper, 11 February 1712, The Hague, Royal Library, $72 \mathrm{H}$ 11. '[Masson] demeure proche d'Utrecht, et il s'entend ou Chinois: car Mr. Réland me mande, que nous aurons une Dissertation de sa façon sur cette Langue'. Cuper to de la Croze, 19 October 1712; Cuper, op. cit. (note 72), no. 33, pp. 108, 113 (as quoted in van Noord and Weststeijn, ibid., p. 361 n. 142).

46 The expertise of the latter was subsequently undermined by other scholars, and needless to say, the mystery of the Siberian mirror was not solved in Utrecht, but by a Chinese scholar in Batavia.

Uffenbach, Merkwürdige Reisen, p. 277. 
of the Hottentot language, ${ }^{48}$ and already translated the whole of the Lord's Prayer with the exception of one word: 'hallowed', as the Hottentot could not find a word to express it. The word 'God' too had to be translated using the Dutch word 'Governor' (Gouverneur), because when Reland asked the man if the Hottentots worshipped anything, maybe the Sun, the latter answered that 'they didn't think that far. ${ }^{49}$ This method of acquiring linguistic information comes as no surprise, for in 1697 Witsen, on the occasion of sending a similar Khoekhoe material, to Leibniz admitted:

Comme je vois, que vous desirez d'avoir le Pater Noster en des Langues de Pais éloignez, je prens la liberté de vous envoyer un Ecrit en Langue Hotentote avec le Credo \& Decem Prcecepta, de même que le Pater Noster en Langue Mogale, le quel j'ay tiré avec beaucoup de peine d'un Mogal Esclave, qui est avec l'Ambassade de Moscovie. S'il y a d'autres Nations Etrangeres parmi eux, je tâcheray d'aprendre aussi leur PaterNoster. $[\ldots]^{50}$

As I see that you wish to collect the Lord's Prayer in the languages of remote lands, I am taking the liberty to send you one written in the Hottentot language, with the Creed and the Ten Commandments, as well as the Pater Noster in the Mongolian language, which I drew with much difficulty from a Mongolian slave, who is with the Moscow embassy. If there are any other foreign nations among them, I will also try to learn their Pater Noster. [emphasis added]

The question remains why Reland would try to produce another Khoikhoi version of the same prayer fourteen years later. Maybe it was just a relatively easy starting point for his more ambitious project of writing a grammar, or more likely, he simply did not know about the documents sent to Leibniz, which were not published until 1717 .

48 Hottentot is the former name for Khoikhoi language spoken in southern Africa, and now largely extinct. In fact, 'the use of the term 'Khoikhoi' meaning 'men of men' or 'people' actually came to prominence in opposition to the offensive label of 'Hottentot' applied to herding communities by white colonialists'; see Mitchell, 'Khoisan Identity'.

49 'Er habe das ganze Vater unser in dieser Sprache zusammen gebracht, nur habe ihm der Hottentot kein Wort sagen können, mit dem er das Wort: geheiliget, wohl exprimiren können. Er habe auch Gott nicht anders als mit dem Hollandschen Namen Gouverneur zu benennen gewust. Als ihn Herr Reland gefragt: ob sie dar gar nichts, und vielleicht die Sonne anbeteten? habe er geantwortet: sie dächten niecht so weit'; Uffenbach, Merkwürdige Reisen, p. 277.

50 Leibniz, Collectanea etymologica, p. 361. 
Reland and Witsen shared another big interest: cartography, and both were directly involved in making maps. In 1705 , Reland dedicated his map of Persia $^{51}$ to

the most magnificent Nicolaes Witsen, renowned for his great merits both in scholarship and, no less, for his honourable commissions to the City Council of Amsterdam and other topmost offices. [...] Whom rare diligence has raised to the highest honours; great man, with an utmost love for the public duty to the City of the Amstel: receive those lands, depicted in the small image, which the sacred water of the Tigris and Indus delineate; the work, approved by your great judgment, will fearlessly face the criticism of many men. ${ }^{52}$

In the corner with the dedication Witsen's family crest is placed at the bottom of a small obelisk. A profile portrait of Witsen is held by an angel with a trumpet and supported — together with a laurel wreath — by a bare-breasted Stedemaagd, the patroness City Virgin, holding the coat of arms of Amsterdam. At her sandaled feet lies an open book and a map scroll with the name Tartarya written across it - a reference to Witsen's opus magnum, Noord en Oost Tartarye (1692, 1705). However, the only known letters from Reland to Witsen survived as handwritten copies accompanying Witsen's letters to Cuper. ${ }^{53}$ While the correspondence with Cuper is quite extensive and will require a separate study, ${ }^{54}$ the letters to Witsen shed some light on Reland's means of acquiring information from overseas. Both letters were written in 1714. Interestingly, when mentioning Cuper, Reland seems obliged to explain that 'for years I have had, and still have, a particular acquaintance' with him, which indicates that his relationship with Witsen was not a very close one. Both letters are similar in the topics dealt with: Reland expresses his learned opinion on some objects Witsen had shown him and shares his linguistic expertise.

These epistolary exchanges reveal just how adept Reland was at both sharing and acquiring knowledge and gaining favours through his letter-writing. For example, in his letter to Witsen dated September 16th, 1714, Reland gave his expert opinion on some Arabic and Turkish coins from Witsen's collection. He was more interested, however, in Witsen's Indian manuscripts containing

$5^{1} \quad$ Cf. the map in Tobias Winnerling's chapter in this volume.

52 Translation by Ulrich Groetsch.

53 I thank Rebeca Fernández Rodríguez and Toon Van Hal for pointing me to these letters.

54 Chen estimates the number of letters exchanged at close to 144 (Chen, 'Digging for Antiquities', p. 18). 
unknown scripts which he had heard about, and about whose provenance he wanted to enquire. He informed the burgomaster that he owned some Javan, Malay, Japanese, Chinese, and other manuscripts himself, and wondered about other scripts still unknown 'to us [Europeans]'. Speaking about the way he acquired the material from Asia, he revealed that the last ships from the East Indies had brought him fourteen printed volumes of Confucius, and that 'Mr Richard Manniks brought for him other Arabic manuscripts on the ship Oetjeskerken'.55 Four manuscripts, however, had been held in the Company's rooms in Amsterdam and he asked Witsen to put a word in to get them back. Two months later, Reland sent another letter to Witsen. This time he was extremely pleased with the unusual book written on tree bark that Witsen had sent to him. ${ }^{56}$ Although he did not recognise the script, from the illustrations he judged that it must originate in one of the Indian islands, maybe Borneo, since little was known about that island. The binding between two wood planks too reminded him of books from Java and Malabar. Reland also complained about his correspondents in Batavia whom he had requested to send back any unknown alphabets and writings, but so far to no avail. He hoped that Witsen might be able to ask the same thing of any competent Company's employees living in Batavia, Ambon or any other place in the interests of science. In the same letter Reland commented on some artefacts that were sent to him. An Arabic celestial globe with a Kufic inscription, 'called so after the city of Kufa on the Euphratus, ${ }^{57}$ showed no major differences compared to the European globes; according to Reland, the names of the stars were the same 'as we [the Europeans] call them' since the Arabs, 'just like us', took their astronomy from the Greek writers. Yet he remarked that the Europeans added the extra work in the form of mathesis, telescopes, etc.

\subsection{Book Exchange and Production}

The exchange of books with publishers and librarians was one of the main topics of Reland's letters. He corresponded with the librarians of several major

55 Richard Munniks, 'procurator' in Batavia from 1711 to 1713, returned to the Netherlands aboard the ship Hoedekenskerke. His brother Johan Louis came from Utrecht; see Valentijn, Oud en nieuw Oost-Indiën, vol. 2, p. 372; vol. 3, p. 161; vol. 4, p. 389; Suid-Afrikaanse argiefstukke: Kaap, vol. 4, p. 372. I thank Bart Jaski for this information.

$5^{6}$ 'In langhen tyd is my niet aengenaemer voorgekoomen, als het boek op bast van bomen geschreeven, dat UW WelEd my heeft gesonden'. Letter Reland to Witsen, 18 November 1714 (Amsterdam, University Library, Ms Bf 82b). Perhaps a palm leaf manuscript, see Appendix 2, A fol 38-40, for three examples in his auction catalogue, from Malabar and Java.

Ibid. 
European collections including Louis XIV, the Bodleian Library in Oxford, and Cardinal Imperiali, for whom Reland was organising a shipment of books from the Rotterdam publisher and bookseller Reinier Leers (1654-1714). ${ }^{58} \mathrm{He}$ also exchanged books with Petrus van der Vorm, or Peter Vorm (1664-1731), a predikant 'minister') in Batavia. 59

It is only regrettable that no correspondence has survived from Reland's contacts with Willem Broedelet who published his major works, Palaestina ex monumentis veteribus illustrata (1714) and De religione Mohammedica (1717). However, there is one extant letter to another influential Dutch printer and bookseller François Halma (1653-1722). ${ }^{60}$ They may have become acquainted with each other when Halma was the university printer in Utrecht, where he is renowned for having printed seven hundred doctoral theses in thirteen years—including Reland's—averaging one per week. ${ }^{61}$ In the letter written from The Hague on 15th May 1700, Reland complained about the tedious task of editing the work of 'our Johannes Andreas', ${ }^{62}$ and revealed his intention to publish his own notes on the Mohammedan Religion 'under the title Miscella Mohammedica or such like' because he 'cannot be cursed to let the written Arabic and Persian histories which I own stay in my possession without any use for the common good'. The work took a few years, but eventually Reland published his De religione Mohammedica in 1705. Reland also expressed the hope that Halma would decide to publish an edition of Inscriptiones antiquae totius orbis Romani by Gruterus (1560-1627) with some notes intended 'to improve and elucidate' made by Mr. van Dalen in Haarlem. This work would serve 'to immortalize Halma's name, if that had not already been done by the Thesaurus Graevii and other pieces', Reland stated somewhat hyperbolically: 'If you would judge that his work could have some place as an adornment of your work, I have no doubt that I could persuade his lordship [van Dalen] that

$5^{8}$ Letter Reland to R. Leers, 28 March 1706, Leiden, University Library, BPL 426 (as quoted in Lankhorst, Reinier Leers (1654-1714), p. 126.).

59 On van der Vorm, see Bart Jaski's chapter in this volume. Serrurier enumerates some other famous correspondents of Reland (Serrurier, Oratio funebris, p. 93). For a full analysis of Reland's correspondents, see Winnerling, 'A Ghost Network', and also Appendix 3.

6o The other letter mentioned in the Leiden University Library catalogue is missing.

61 Forrer, 'Dutch Academic Theses and Printed Matter', p. 57.

62 Juan Andrés, Latinized Joannes Andreas (ca 1450-after 1515), is the Christian name taken by the Spanish Muslim jurisprudent and scholar, originally known as Ibn 'Abdallāh, after he converted to Catholicism and became a missionary. He is the author of a well-known polemical work against Islam, Confusión o confutación de la secta mahomética y del Alcorán (1515) (Zuwiyya, 'Juan Andrés'). He was an important source for Voetius' Disputatio De Mohammedanismo (cf. Christian Lange's chapter in this volume). It is striking to note that Andrés is at least partly what triggered Reland's work on De religione Mohammedica. 
in due course you would obtain it and publish it'. Indeed, Iani Gruteri Corpus Inscriptionum was published by Halma in $1707 .{ }^{63}$ Their collaboration must have extended beyond Halma's years in Utrecht, as it is hard to think that the grammar of Sinhala, Grammatica of Singalëse taal-kunst, zijnde een korte methode om de voornaamste fondamenten van de Singalese spraak te leren, written by Joannes Ruëll in 1699, could have been prepared for the press without any help from an accomplished linguist. It was printed by Halma in 1708, when he had already moved his business to Amsterdam, and featured the first Sinhalese letters printed in Europe. Reland announced the 'imminent publishing' of this book in his Dissertationum miscellanearum, ${ }^{64}$ and also got a copy of it for his own library. Since the publication was ordered by Witsen as an internal voc item, and since it eventually reached the Dutch Seminary in Sri Lanka for which it was intended, it is easy to see how close the author-scholar-patronpublisher network really was in The Dutch Republic.

\section{$4 \quad$ Reland the Colleague and Friend}

\subsection{Let the World Come to Utrecht}

Although Reland himself admitted that he did not like travelling 'further than necessary'65 (even though in his De religione Mohammedica he revealed that he would have loved to visit Constantinople), he eagerly befriended people who did. Among his 'good friends' he counted the 'famous traveller' and artist Cornelis de Bruijn ${ }^{66}$ (1652-1727), nicknamed Adonis in the Dutch artistic circles in Rome ${ }^{67}$ - and his flamboyant portrait testifies to why [Fig. 10.4].

63 One of Reland's colleagues, the eminent classicist Peter Burmann (1668-1741) was accused by the famous biblical scholar Jean Le Clerc $\left(1657^{-1736)}\right.$ of persuading Halma to embellish this edition with the images of the Greek god of fertility, gardens, and male genitals Priapius, with his attribute being a giant phallus. Burmann denied the allegations yet he ridiculed Le Clerc's prudishness saying that even if he had, he would not be ashamed since the book was not destined for ladies or young people, but for older scholars who are used to seeing nude paintings and statues (Burmann, Le gazettier menteur, ou Mr. Le Clerc convaincu de mensonge de et calomnie (1710), pp. 56-57). Burmann was a probable target (and possibly the culprit) as he was known for the new edition of the controversial Satyricon by Petronius, whom Le Clerc described as 'the most obscene author from classical antiquity' (cf. Groetsch, 'The Scholar as Whoremonger', p. 566).

64 Reland, Dissertationum miscellanearum pars tertia et ultima, pp. 81-82.

65 'Pour moi, qui ne prens aucun plaisir à faire de si long voyages sans necessité [...]' in Lettre à son excellence monseigneur le comte de Kniphuisen, p. 3 .

66 Letter to Witsen, 1714, Amsterdam, University Library, Ms Bf $82 \mathrm{~b}$.

67 For over two years of his stay in Rome, de Bruijn was a member of the Dutch and Flemish society of painters called Bentvueghels, 'Birds of a Feather', better known for their 


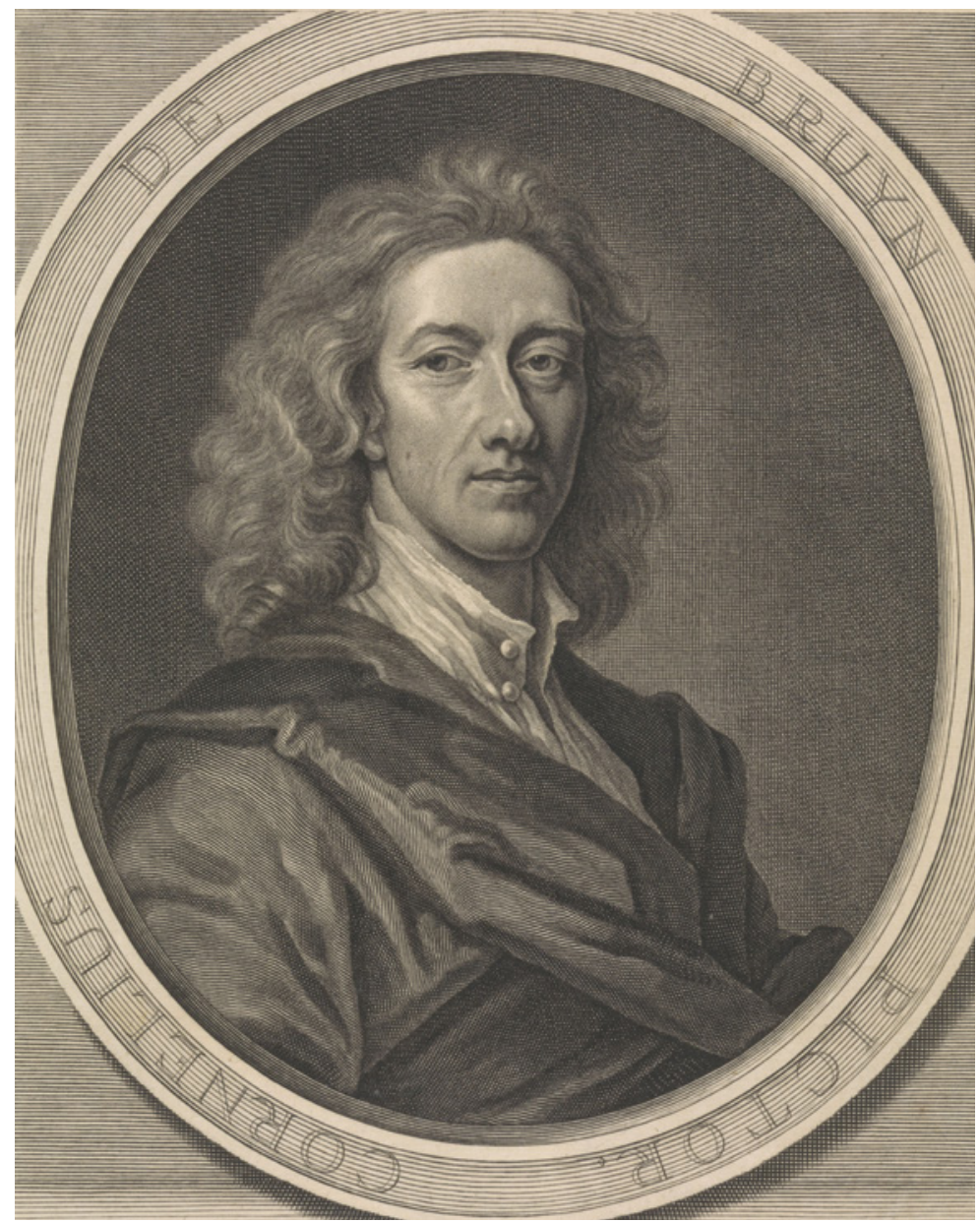

FIGURE 10.4 Cornelis de Bruijn by Gerard Valck (after Gottfried Kneller, Rijksmuseum, RP-P-19o6-2511)

De Bruijn travelled the world 'from Rome to Jerusalem and from Moscow to Batavia,68 and became famous for his travelogues and illustrations, including the most detailed drawings of Persepolis (where he vandalised a stone on the Gate of All Nations, carving his name on it), Jerusalem, and the first ever drawings of the interior of the great pyramid in Giza (where he climbed to the top and also left his signature there). In his Reizen door Klein Asia from 1698,

exuberant initiation rituals, libations, and drinking bouts than for their artistic pursuits.

68 Jurriaans-Helle, Cornelis de Bruijn. Voyages from Rome to Jerusalem and from Moscow to Batavia. 
De Bruijn - in a likely collaboration with Valk and Schenk-experimented with colour print using a pioneering technique developed by Johannes Teyler. ${ }^{69}$ Very early on his works attracted the attention of Witsen and Cuper, who became his benefactors. De Bruijn's first-hand experiences of the Middle East and Asia must have been an invaluable source of information for Reland - and not only that: at the end of Reland's Manuscript Catalogue, there is also a list called Fragmenta Antiqua Inscriptiones with three archaeological fragments $e x$ ruderis Persepolitanis (from the rubble of Persepolis). ${ }^{70}$ Who else but De Bruijn could have procured them for Reland? Perhaps it was a gift, or maybe the professor bought it from De Bruijn when the latter, financially strained by selffinancing his books, stayed for some time with friends in Utrecht or Haarlem, and started selling his rarities out of necessity, as Uffenbach suspected? ${ }^{71}$ In any case, when Uffenbach visited De Bruijn in his house in Amsterdam in March 1711, he marvelled at 'many beautiful drawings and antiquities': ${ }^{72}$

The most extraordinary are the rubble of Persepolis, various figures and inscriptions which, as he assured us, he removed and brought back with him, but mostly sold to the Duke of Wolfenbüttel, Mayor Witsen and other lovers [of antiquity]. He only had a few inscriptions left, which he showed us. One cannot be surprised enough at the great effort this man put into [copying] the inscriptions, which consist of very strange characters, and which neither the current inhabitants of the country nor anyone else understands. Mr. Reland and other lovers of languages and antiquities in Holland have tried very hard to decipher something, and Mr. Cuperus has also sent many sketches to foreign scholars, but to no avail. He assured him that at first it would be an unbelievable effort to copy the inscriptions because he knew no letter or character at all. ${ }^{73}$

69 Gnirrep, 'Een experimentele kleurendruk', pp. 6o-61.

70 The other items mentioned in it are 'some minerals', two Florentine dendrides [?], and a clay frustum with an Etruscan inscription. The stone fragments are mentioned on the title page of the auction catalogue as having been brought by 'de Bruinio ex Persia'.

71 Bruyn, Reizen over Moskovie, pp. 100-101.

72 'Es sind darunter sehr viele schoene Gegenden, und andere curioese Dinge. Das merkwuerdigste aber sind de Rudera von Persepolis, davon er so gar, wie er versicherte, verschiedene Figuren und Inscriptionen ausgehauen und mitgebracht, so er aber meistentheils an den Herzog von Wolfenbuettel, Burgermeister Witsen und andere liebhaber verkaufft [...]', Uffenbach, Merkwürdige Reisen, p. 676.

73 In fact, the decipherment of the cuneiform script only occurred in 1836 as a result of the work of the French scholar Eugène Burnouf (1801-1852) and the Norwegian-born Orientalist from the University of Bonn, Christian Lassen (1800-1876). 


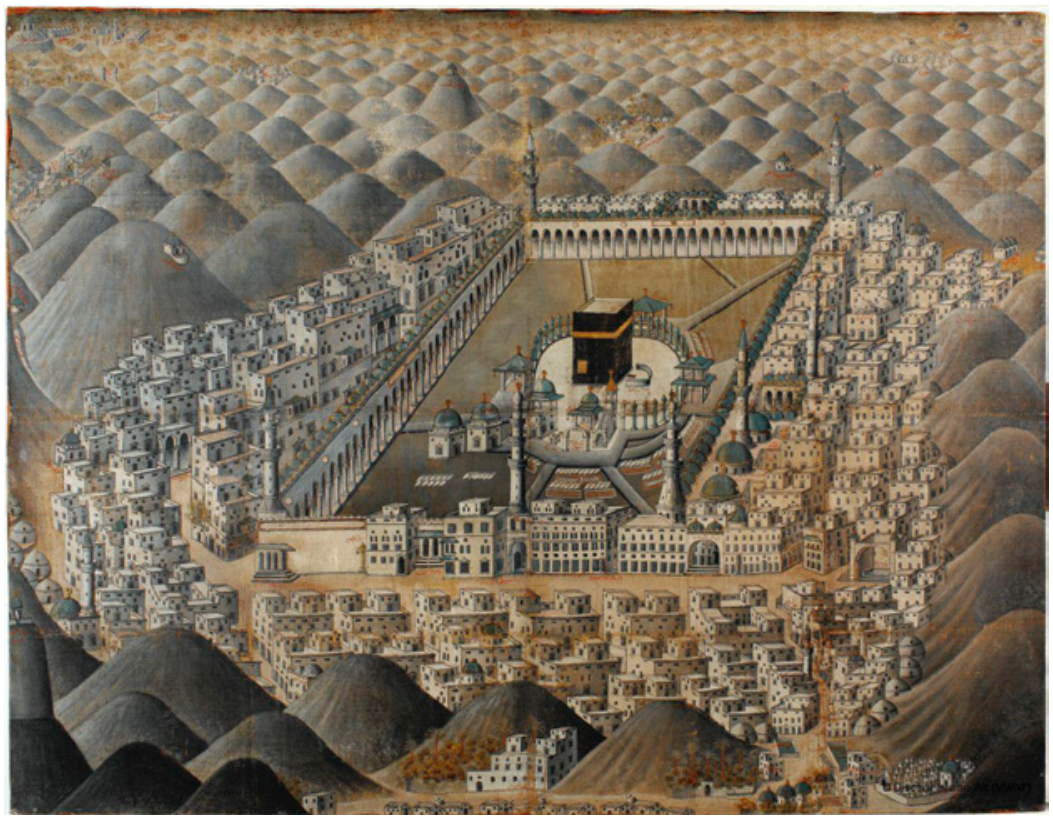

FIGURE 10.5 Mecca with Ka'ba, oil painting, early 18th century, Uppsala University Library (UU 2372)

Another traveller whom Reland met at home was the Swedish professor Michael Eneman (1676-1714), who stopped in Utrecht on his way from the Middle East back to Uppsala in 1714. Eneman showed Reland the painting of Mecca he acquired during his travels [Fig. 10.5], ${ }^{74}$ of which Reland made a copy and published in the second edition of his De religione Mohammedica libri duo from 1717. As it happened, it was the first printed depiction of Mecca with its holiest shrine the Kaaba [Fig. 10.6].

In the same book Reland reminded his readers that a man does not need to leave his birth place in order to know geography: refuting the thesis that Muhammad did not know where Mecca was, even though he composed his Surah there, and mistakenly thought it was in the Ammonite land (modern day Jordan instead of Saudi Arabia). Reland stated that it would be as unlikely

74 It was actually Michael Edeman's companion Johan Silfwerkrantz, who had bought the paining in Cairo in March 1712, according to his own unpublished diary discovered by Johan Held from Uppsala University. When Silfwerkrantz died during the return journey, Eneman kept the painting, which was donated to the University Library in 1717 after his premature death in the same year (Johan Held, personal communication). 


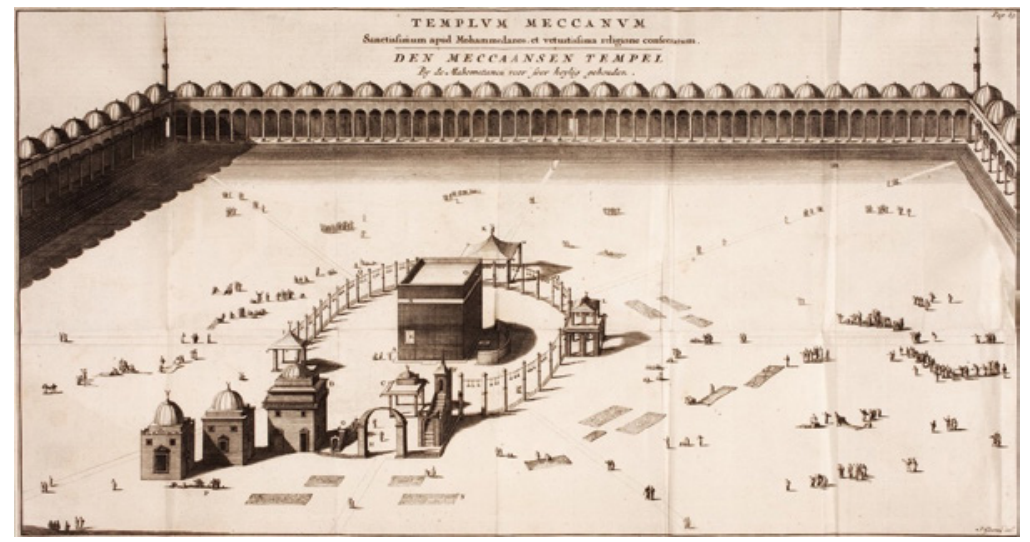

FIGURE 10.6 Templum Meccanum in Reland's De Religione (1717)

as if he himself, writing these words in Utrecht, claimed that Utrecht was in Switzerland. ${ }^{75}$

\subsection{Gifts and Dedications to Friends}

The physical copies of books which Reland received as gifts, as well as his dedications, offer a further insight into his social network. ${ }^{76}$ Close to home, Reland was involved in contemporary debates on his native language. He was one of the recipients of open letters from the Amsterdam Mennonite mercator sapiens, amateur mathematician and grammarian Adriaen Verwer (ca. 16551717), who wrote them in defence of his linguistic views expressed in his Latin grammar of Dutch, Linguae Belgicae idea grammatica, poetica, rhetorica, from ${ }^{1707 .}{ }^{77} \mathrm{He}$ also sent Reland a copy of Lambert ten Kate's Gemeenschap tussen de Gottische spraeke en de Nederduytsche ('The Relationship between the Gothic and Dutch languages', 1710), a book inspired by Verwer and his gothica-genetrix theory of Gothic as the source of all Germanic languages, which the professor acknowledged in a letter from $1710 .{ }^{78}$

75 Reland, De religione (1717), p. 171: 'Idem hoc est, ac si nos Trajectum ad Rhenum, ubi haec, scribimus, in Helvetia sitam esse affirmassemus'.

76 Reland's books and manuscripts are also discussed by the contributions of Bart Jaski and Anoud Vrolijk in this volume; see also Appendix 2.

77 Verwer, Brief aen den Heere Adriaen Reland.

78 Noordegraaf, 'From "Radical Enlightenment" to Comparative Historical Linguistics', pp. 155-168; see also Reland's letter to Verwer of 15 May 1710, Utrecht, University Library, Ms 6 F 29, no. 16, edited in Ten Kate, Gemeenschap tussen de Gottische spraeke en de Nederduytsche, pp. 13 and 22-23. 
Probably the most spectacular gift he received was the eleven-volume Latin edition of Atlas Maior by the Dutch cartographer Joan Blaeu (15961673) and 'excellently coloured with gold, ultramarine, etc.' by Dirk Janz. van Santen..$^{79}$ The note from Gerard Meerman (1722-1771), who bought the book at auction in 1761 , says that the atlas was presented to Reland by Utrecht University on the occasion of the birth of his son, ${ }^{80}$ whose name is not mentioned and only a blank space left for where it was to be written. ${ }^{81}$ The atlas came with a custom-made 'quaint French ebony chest with two glass doors' to keep it in.

Among other valuable gifts we find two Malay manuscripts presented to Reland by François Valentijn (1666-1727), a somewhat controversial Dutch naturalist and minister in service of the Dutch East India Company. ${ }^{82}$ One of them is the Historia Prophetae Mosis sermone Malaico, ${ }^{83}$ and the other is Hikayat Ismayatim [Fig. 10.7].

In the collections of the Royal Library in The Hague one can find a small book bound in ornamented leather [Fig. 10.8]. It contains two works, an abcedarium to teach children to read, and a Chasovnik - a Russian prayer book, printed in Moscow in the year 7145 of the Byzantine calendar (i.e. 1637 AD). ${ }^{84}$ The dedication of the front page reads 'Relando suo Sikius'.

An identical dedication is mentioned in a couple of other books from Reland's catalogue, ${ }^{85}$ including Meletij Smotrickij's Slavonic grammar ${ }^{86}$ and

79 It appears not to have found a buyer at the auction in 1718, since it was still the pièce de résistance of his son's auction catalogue 46 years later, when it was bought for the collection of the current Museum Meermano in The Hague.

8o Jan Hubertus Reland was baptised as 'Iohan Hubartus' on August 19th, 1716, eighteen months before Reland's death.

81 I owe this information to Erik Geleijns, Curator of Early Collections of the Museum Meermanno.

82 On Reland's contacts in the Orient, esp. Valentijn, Petrus van der Vorm, and Cornelis Mutter, see the contributions by Bart Jaski and Arnoud Vrolijk in this volume.

83 Utrecht University Library, MS 1482.

84 To read more about this book, see Marieke van Delft's book history blog post 'Over de knie in Rusland' (2012) available at https://www.kb.nl/blogs/boekgeschiedenis/ over-de-knie-in-rusland.

85 See Appendix 2 in this volume, A qua 16, oct 13, 29, 35, 37, C 7, D 6.

86 Cambridge University Library, K. 247. Reland's interest in Slavic languages requires further study. From his catalogue we know he owned a few books in various Slavic languages. Also, at the end of the Dissertationum miscellanearum, pars tertia et ultima, 1708, pp. 81-82, there is a list of translations of Our Father into thirteen 'dialects of Slavonic languages': Cyrillice, Bulgarice, Dalmatice, Croatice, Sclavonice, Bohemice, Polonice, Vandalice, Lusatice, Moscovitice, Carniolice, Novazemblice, and Walachice. 


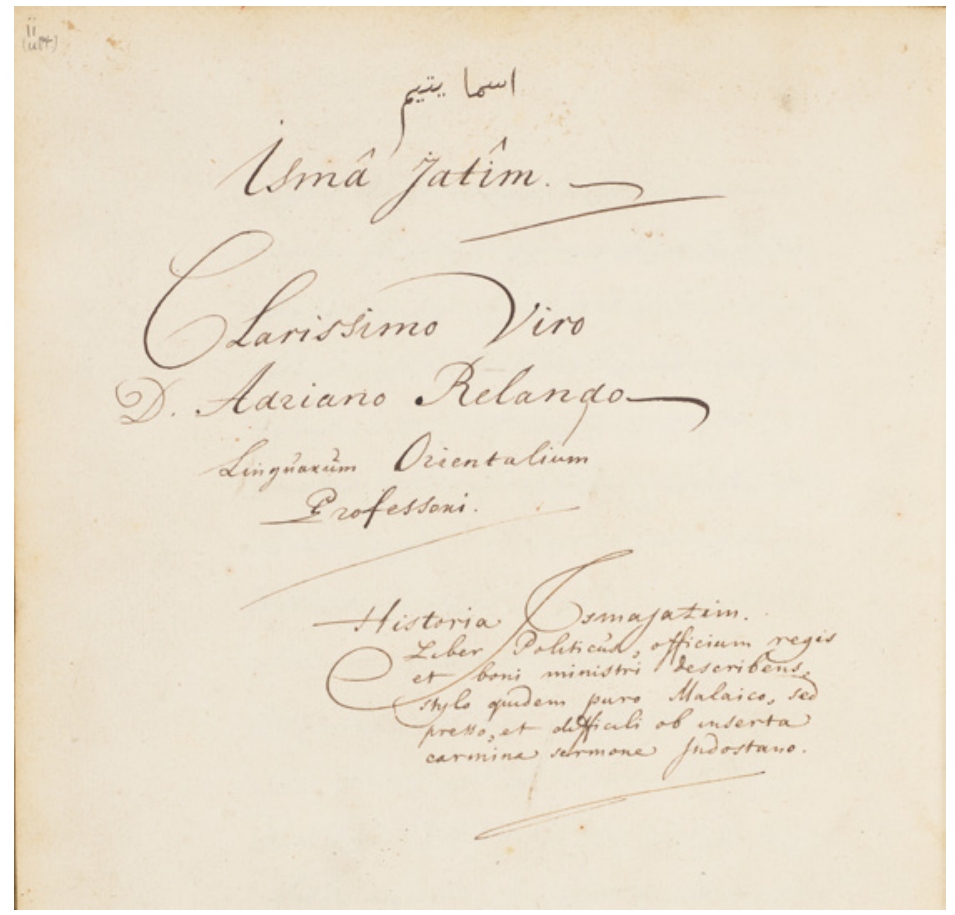

FIGURE 10.7 A dedication from Valentijn to Reland on Hikayat Ismayatim (The University of Manchester, The John Rylands Library, Malay MS 3)
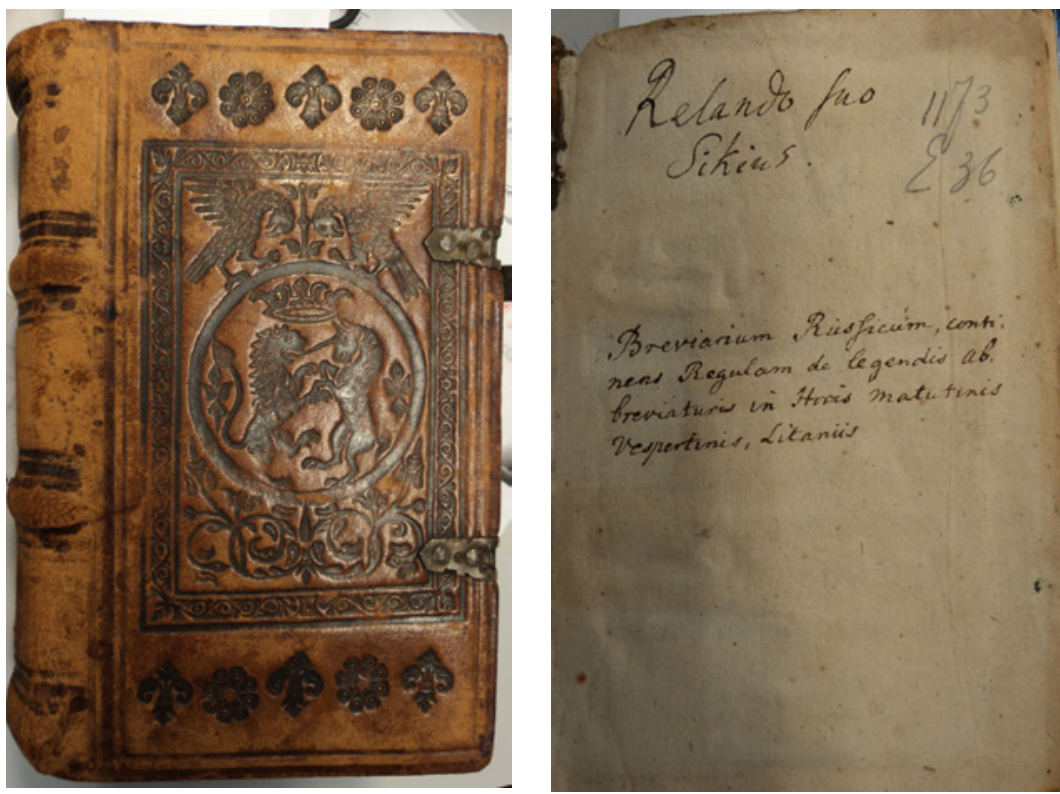

FIGURE 10.8 The Russian abecedarium and a prayer book with dedication from Sike to Reland (кв inv. no. 1173 E 36 ) 


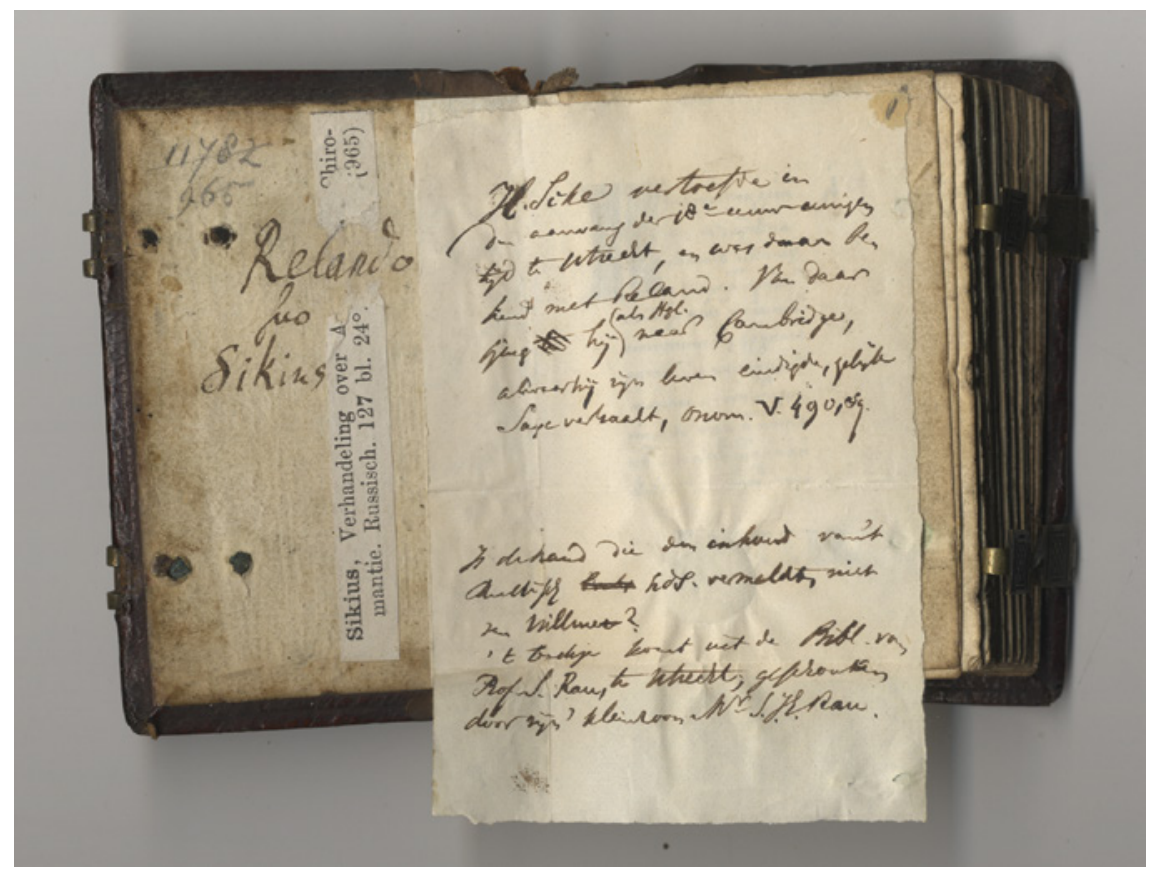

FIGURE 10.9 A dedication from Sike to Reland in the Russian Orthodox Calendar of Saints (Leiden University Libraries, Maatschappij der Nederlandse Letterkunde LTK 965)

another Russian book 'pertaining to astrology and chiromancy' according to the Catalogus der Bibliotheek van de Maatschappij der Nederlandsche Letterkunde te Leiden (1864), p. $33 \cdot{ }^{87}$ The latter is actually a manuscript of a Russian Orthodox Calendar of Saints from c. 1593, rediscovered by Arnoud Vrolijk in the Special Collections of Leiden University Libraries [Fig. 10.9]. ${ }^{88}$

The 'Sikius' mentioned in the dedications was Heinrich Sike (1669-1712), an outstanding Oriental scholar from Bremen, who taught Arabic to Reland in Utrecht and developed a friendship with him. Sike gained fame for translating the Syriac Infancy Gospel, an apocryphal text of the New Testament describing the infancy of Jesus and publishing it as a bilingual Arabic-Latin edition. ${ }^{89}$ He also produced a Latin translation of the Qurānn, now lost. Sike, who started

87 This reflects the entry in the auction catalogue of 1761 , see also Appendix 2, A oct 29.

88 See Arnoud Vrolijk's chapter in this volume.

89 Sike, Evangelium infantiae, vel Liber apocryphus de infantia Servatoris (1697). 
his career as a soldier in Levant, was notorious for his uncouth style and for smoking tobacco. ${ }^{90}$ However, his competence in Arabic and Hebrew was unparalleled, yet he lacked any formal qualifications, and when he was considered for the position of Professor of Hebrew in Cambridge, his colleagues from the circle of learned men in Utrecht-including Reland-decided to help by conferring on him a degree modo extraordinario of Liberalium artium Magister et philosophiae doctor (M.A. and a doctorate). ${ }^{11}$ Once in Cambridge, Sike became friends with Richard Bentley and others, including Isaac Newton. Tragically, on May 2oth, 1712 he committed suicide. In his letter to Bentley from July 23 rd 1712, Reland laments the death of his friend:

At quam me turbavit nuncius horribilis! In hunc usque diem fidem habere non potui rumoribus de Sikio nostro circumlatis. Nunc coram se testem fuisse infandi spectaculi affirmat Crownfieldius. O infelix fatum! et damnum quod literae nostrae patiuntur vix reparabile! ${ }^{92}$

But how disturbed am I by the horrendous news! Up to this point, I could not believe the reports circulating about our Sike. Crownfield confirms now that he witnessed this shocking spectacle. Oh, tragic fate! And what loss to our Letters, barely reparable!

Cambridge University Library holds a remarkable gift Sike received in 1703 from Engelbert van Engelen (ca. 1650-1723), city doctor of Utrecht, when Sike was embarking on an extended journey with the Earl of Huntingdon 'into remote foreign lands'. An Arabic manuscript entitled 'El breve compendio de nuestra santa ley alçunna' ${ }^{\prime 3}$ is a compendium of Islamic law written in Aljamiado, i.e. Spanish transcribed in Arabic characters. ${ }^{94}$ According to the Biographisch woordenboek der Nederlanden, van Engelen was born in Arnhem and studied medicine at Leiden before settling in Utrecht. Like Reland, he was a keen

9o Sike shared this vice with another Utrecht professor, Peter Burmann, who not only authored a Macaronic panegyric on pipe-smoking, but was also infamous for an alleged rape of a house maid, of which he was eventually acquitted (cf. Groetch, 'The Scholar as Whoremonger', p. 563). Reland, who in a letter called Burmann his 'collega conjunctissimus' [closest colleague], was aware of the affair since, according to the court case transcripts, the matter was discussed at a professors' dinner which Reland hosted at his house on December 2oth and 21st, 1708 (Proces, geventileert voor den Ed. Gerechte van Utrecht, pp. 35, 54).

91 Forster, 'Henry Sike of Bremen (1669-1712)'.

92 The Correspondence of Richard Bentley, pp. 433-434.

93 Cambridge University Library, Ms Dd.9.49.

94 Cf. Ansorge, 'From Andalusia to Cambridge' [web blog]. 
historian of numismatics, as is attested by an official dedication to his name (next to De Wilde et al.) on the front page of Medalische historie der Republyk van Holland from 169o. Not surprisingly, Reland had a good relationship with the much older Dr van Engelen, who once presented him with a precious antique object. Reland's gushing thank you letter to van Engelen is preserved in Leiden University Libraries: ${ }^{95}$

Sir,

Although I am perfectly aware that the Egyptian Isis is a gift far above the one I sent you, and therefore it should be with a great difficulty that I accept it, first, do not let me deny the pleasure and kindness you have bestowed on me, and on the other hand, the love and regard that I have for the remains of Antiquity. I cordially thank you for it, and I can assure you that it could not have been given to anyone with more esteem [for it], and more sincerely asserted.

Sir,

Your affectionate friend and servant

A. Reland ${ }^{96}$

\subsection{Alba Amicorum, or Facebook CE $1700^{97}$}

In 1713, Reland wrote an inscription in Van Engelen's album amicorum [Fig. 10.10], dedicating it to Viro Doctissimo, Medicinae Doctori, Antiquitatum patriarum aliarum que amatori singulari with a sentence in Greek from the Enchiridion of the Greek Stoic philosopher Epictetus: 'It is much more necessary to cure the soul than the body; for death is better than a bad life': 98

95 Reland to E. van Engelen, Leiden University Libraries, PAP 15.

96 'Omme de Heere van Engelen, Stads Doctor. Myn Heer, Schoon ik my genoegsaem bewust ben dat de Egiptische Isis een present is verre te bovengaendt het gene van my aen UEd. gesonden is, en daerom difficulteit soude kunnen gemaektt werden om deselve teaccepteren, laet my eensdeels UEd. genegentheyt en beleeftheyt, anderdeils de liefhebbery en agting die ik voor de overblyfsenel der outheyt heb, niet toe het selve te weygeren. 'K seg er UEd. dan hertelik dank voor en kan UEd. versekeren, 't kon aen niemant gegeven zyn die het meerder agt, en sig ongeveynsder betuygt te zijn Mijn Hr UEd. Genegen Vriend en D.A. Reland'.

97 I borrowed this analogy from The Guardian article 'Alba amicorum: the original Facebook for Renaissance teens?', 5 Dec 2018, https://www.theguardian.com/books/2018/dec/o5/ british-library-alba-amicorum-renaissance-facebook, (accessed 18 January 2020).

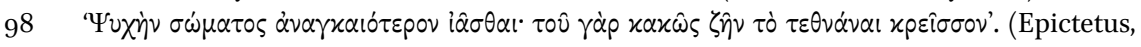
The Discourses as Reported by Arrian, the Manual and Fragments, fr. 32). With thanks to Gert M. Knepper who transcribed and identified the fragment. Reland edited Meiboom's translation of Epictetus (see also n. 3 above). 


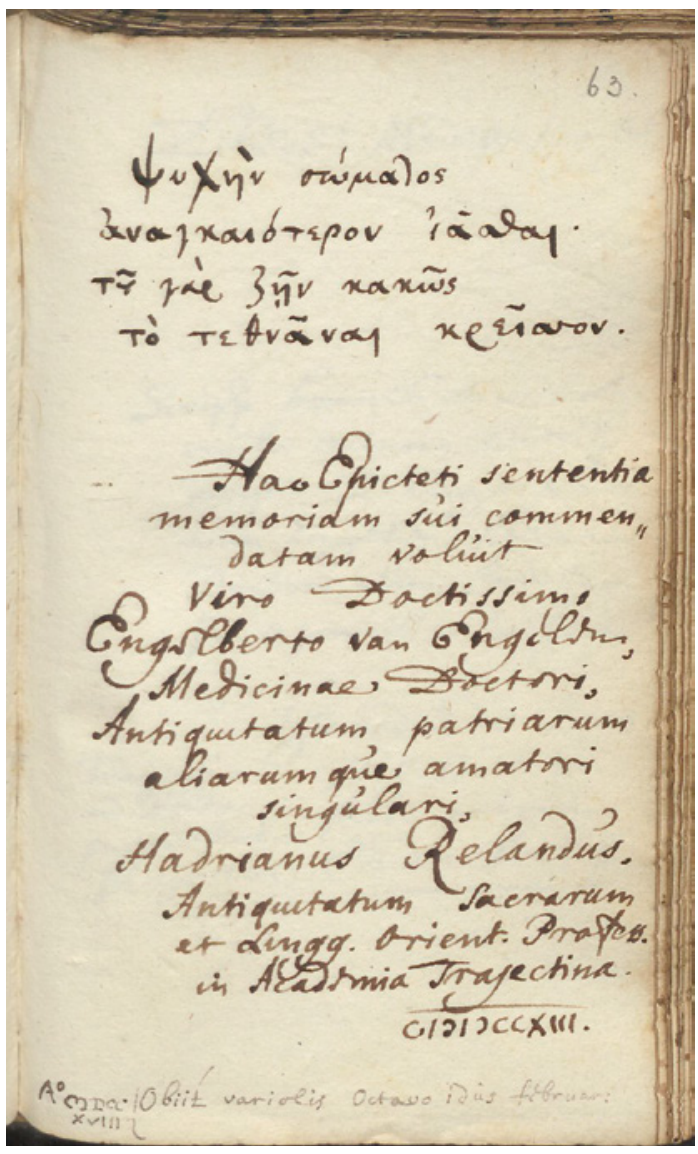

FIGURE 10.10

Reland's album amicorum inscription for Engelbert van Engelen (Leiden University Libraries, MS PAP 21 f.63)

Reland's signature includes his freshly acquired title of Antiquitatum Sacrum Professor (professor of Hebrew Antiquities). Judging from the number of preserved multilingual and multi-scriptural entries, always neatly written, in various alba amicorum, Reland must have been an affable colleague to an international crowd of Holland-based scholars and travelling students. In 1701, the juristconsul Arnold Kerseboom received a neatly written Arabic quotation from Theologiae Mohammedicae Interpretatione with the Latin explanation. In 1709, Clasenius received a verse from Valerius Flaccus' Argonautica: 'Eripe te populis et habenti nubila terrae' ('raise me above the nations and the cloud-wrapped earth'), signed simply Lingg. Orient. Prof. (Professor of Oriental Languages). In 1706, the Ulster-Scottish Presbyterian theologian Samuel Haliday (1685-1739), then a student in Leiden and 'an excellent young man', received a maxim in Arabic 'man ya'muryalqa fìnafsihi mā yatamannāhu li-a'dāyih' ('Whoever gets 


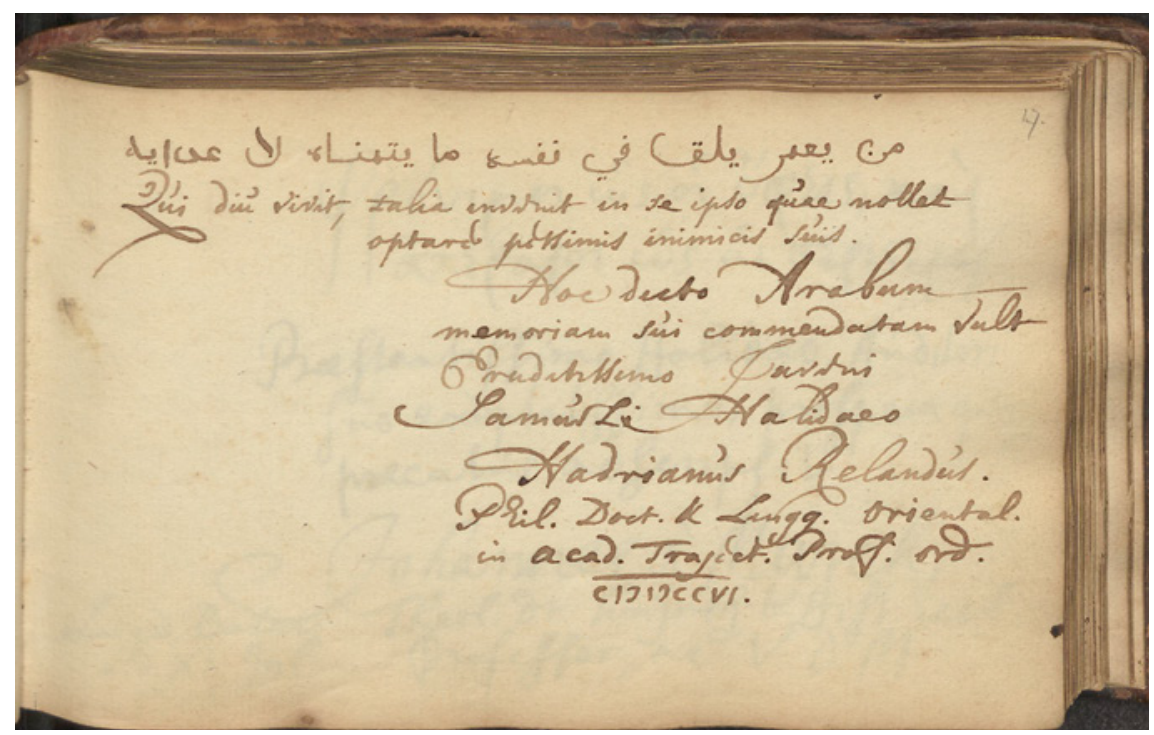

FIGURE 10.11 Reland's inscription for Samuel Haliday (Leiden University Libraries, MS AHM 8)

old encounters in himself what he wishes upon his enemies' $)^{99}$ with the Latin translation: 'Qui diu vivit, talia invenit in se ipso quae nollet optare possimis inimicis suis' [Fig. 10.11].

In the same year, the German cartographer and engraver Pieter Schenk the Elder (166o-1711), 'cosmographus et artifex incomparabilis', ('incomparable cosmographer and artist') was given a line from the Roman epic poet Lucan: Non sibi sed toti genitum se credere mundo ('To believe that he was born to serve the whole world and not himself') [Fig. 10.12].100

Schenk, who completed an apprenticeship with the Amsterdam engraver and map publisher Gerard Valck (and later married his sister Agatha), initially specialised in portraits, among others of mayors of Amsterdam, including Witsen, and topographical landscapes. From ca. 168o he started operating with his brother-in-law as 'Valk and Schenk', publishing various maps and atlases, and from 1701 on specialised in making the best globes in the Netherlands. In 1703, Schenk made a mezzotint portrait of Reland which we can see in the visitors' book cum album amicorum of Nicolas Chevalier (1661-1720) [Fig. 10.13]. He collaborated with Reland on his map of Persia (1705). Chevalier, the French Huguenot book trader and antiquarian, fled to Amsterdam from Sédan after

99 Transcription and translation with thanks to Christian Lange.

100 Lucan [Marcus Annaeus Lucanus], The civil war, book 2, line 383 . 


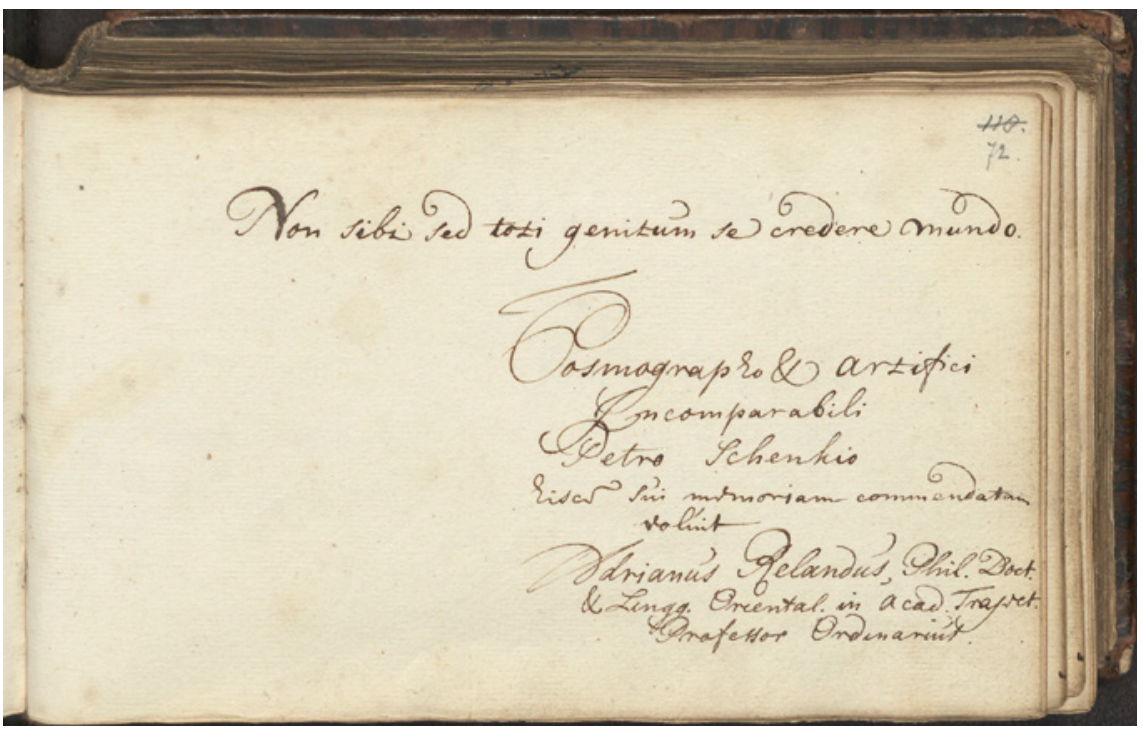

FIGURE 10.12 Reland's inscription for the cartographer Peter Schenk (Leiden University Libraries, Ms $9 \circ 3$ f. 72r)

the revocation of the Edict of Nantes in 1685. The book contains 260 entries from the most famous people of his time, from Witsen, Cuper, J.G. Graevius, Peter Burmann, to - and the most curious of all-Matthias Buchinger (16741739), a Bavarian dwarf from Neurenberg, born without hands and feet, who became a calligrapher specialising in intricate micro-graphics. Reland's inscription from 1703 is written on the verso of page 120 with his mezzotint portrait by Pieter Schenk on the recto. The dedication to Viri Erudissimi et antiquitatum Scrutatori indefesso ('the tireless investigator/searcher of antiquities ...') follows a couplet in Persian from the second chapter of Saadi's Bustan ('The Orchard'): 'Though God, in his wisdom, closed one door/ another in his mercy, did he open' [Fig. 10.13]. ${ }^{101}$

Enough is known about Chevalier's activity to allow a speculation on what Reland meant by this quotation. The exhibition of the 'chambre des raretez', or the cabinet of curiosities, which this guest book accompanied, had been open in Amsterdam since 169o. In 1703 Chevalier moved with it to Utrecht. Reland apparently visited the cabinet at its new location, and probably knew the reasons that pushed Chevalier out of Amsterdam. Fortunately, the latter soon established himself in Utrecht as a licensed medallion maker.

The ultimate expression of friendship and respect that Reland earned among his peers can be found at the end of his Oratio funebris. In a tribute to

101 I owe this information to Gijs Kruijtzer who identified the passage. 
his passion for languages eleven of his colleagues wrote poems and eulogies in five languages and in five different scripts. His former teacher, the theologian Melchior Leydecker (1642-1721) wrote an opening poem in Hebrew; Latin eulogies followed by the Deventer professor of philosophy Dionysius Andreas Röell (1689-1734); the pastor Henricus Brink; the professor of theology and rector of the University of Copenhagen Johannes Wandalinus; the jurist Eduard van Zurk, the author of Codex Batavus; the poet and linguist David van Hoogstraten (1658-1724); and Johann Hildebrand Withof (1694-1769), who studied in Utrecht at the time. In the part entitled Pietatis Officia Manibus, the professor of theology Hieronymus S. van Alphen $\left(1655^{-1742}\right)$ dedicated to Reland a few verses in Hebrew; Reland's young student of theology and Oriental literature Emo Lucius Vriemoet (1699-1760) left some Arabic verses; Petrus van der Hagen (1697-1762), later minister in Utrecht, wrote in Greek; finally, the theologian Franz Smit from Bremen (1695-1746) left an inscription in Old Slavonic. 'Sometimes we lose friends for whose loss our regret is greater than our grief, and others for whom our grief is greater than our regret' observed La Rochefoucauld. ${ }^{102}$ Reland's premature death seemed to have evoked equally the regret of losing a brilliant scholar and the grief of saying farewell to an affable and highly regarded companion.

\section{$5 \quad$ Conclusions}

Behind the impressive intellectual legacy left by Reland hides an obscure and somehow forgotten man of flesh and blood, known only from a couple of portraits. The last mental picture of Reland was recorded probably by Serrurier:

He was a man of great hopes had he lived longer, honest and modest. He was taller than average, well built, with a handsome and happy face; one could see the marks of this gentleness and goodness he really possessed in his character shining through. [...] He lived harmoniously with his colleagues, who did not find it hard to grant him their respect and friendship; he never spoke or wrote with acrimony [...] and it was hard to become an enemy of an opponent so honest and polite. ${ }^{103}$

\footnotetext{
102 'On perd quelquefois des personnes qu'on regrette plus qu'on n'en est affligé; et d'autres dont on est affligé, et qu'on ne regrette guère', F. La Rochefoucauld, Maximes et réflexions morales, no. 355 .

103 Translation mine. Quoted after the French interpretation in the Journal littéraire de l'année M.DCC.XVII: 'C'étoit un homme d'une grande espérance, s'il avoit vécu plus longtems, honnête \& modeste. Il étoit d'une taille au-dessus de la médiocre, bien fait, beau de visage, \& d'une physionomie heureuse; on y voyait briller les marques de cette bonté \& de
} 


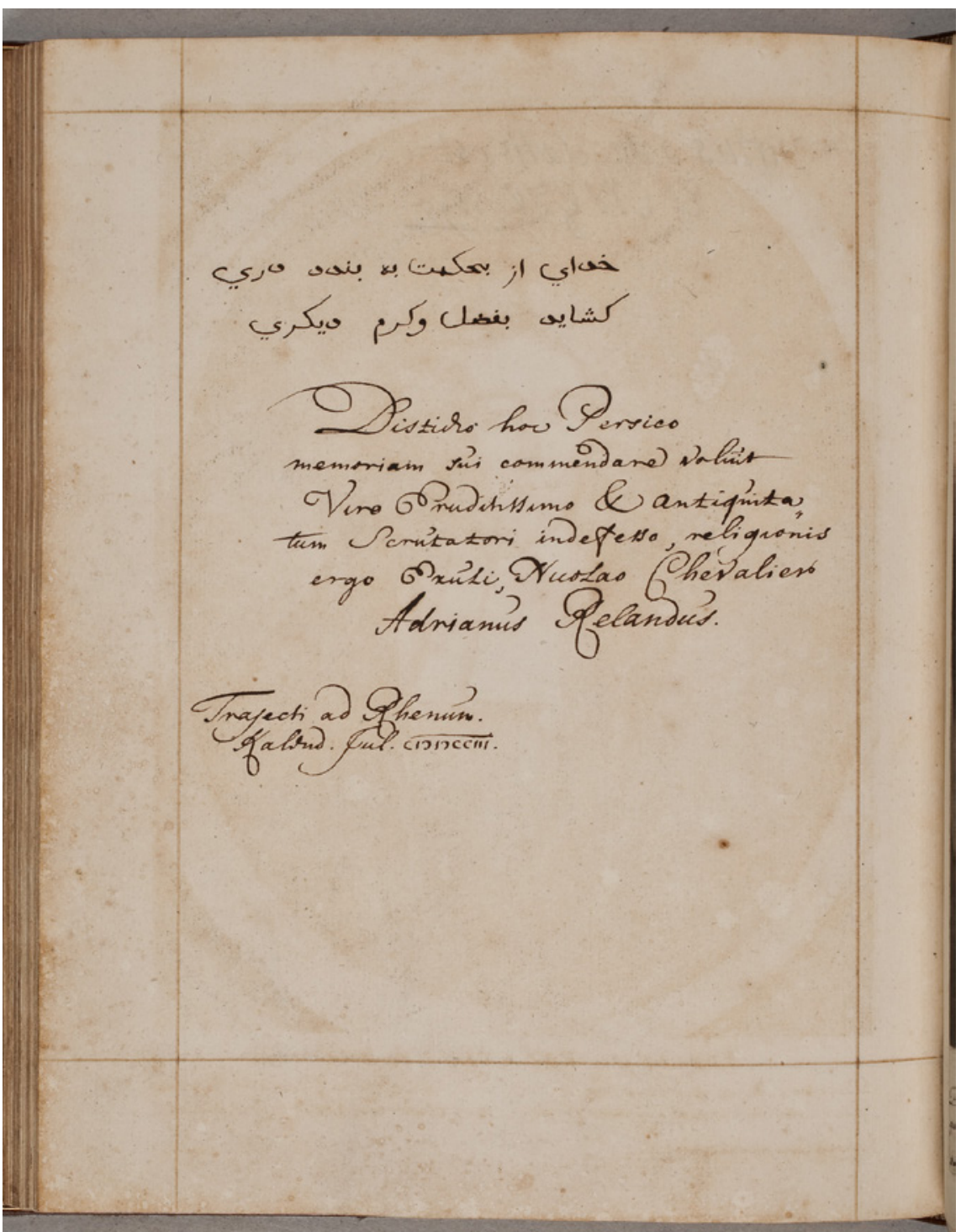

FIGURE 10.13 Reland's inscription for Nicolas Chevalier (Den Haag, Koninklijke Bibliotheek: 69 B 8, f. 120v) and the portrait by Pieter Schenk (f. 120 r) 


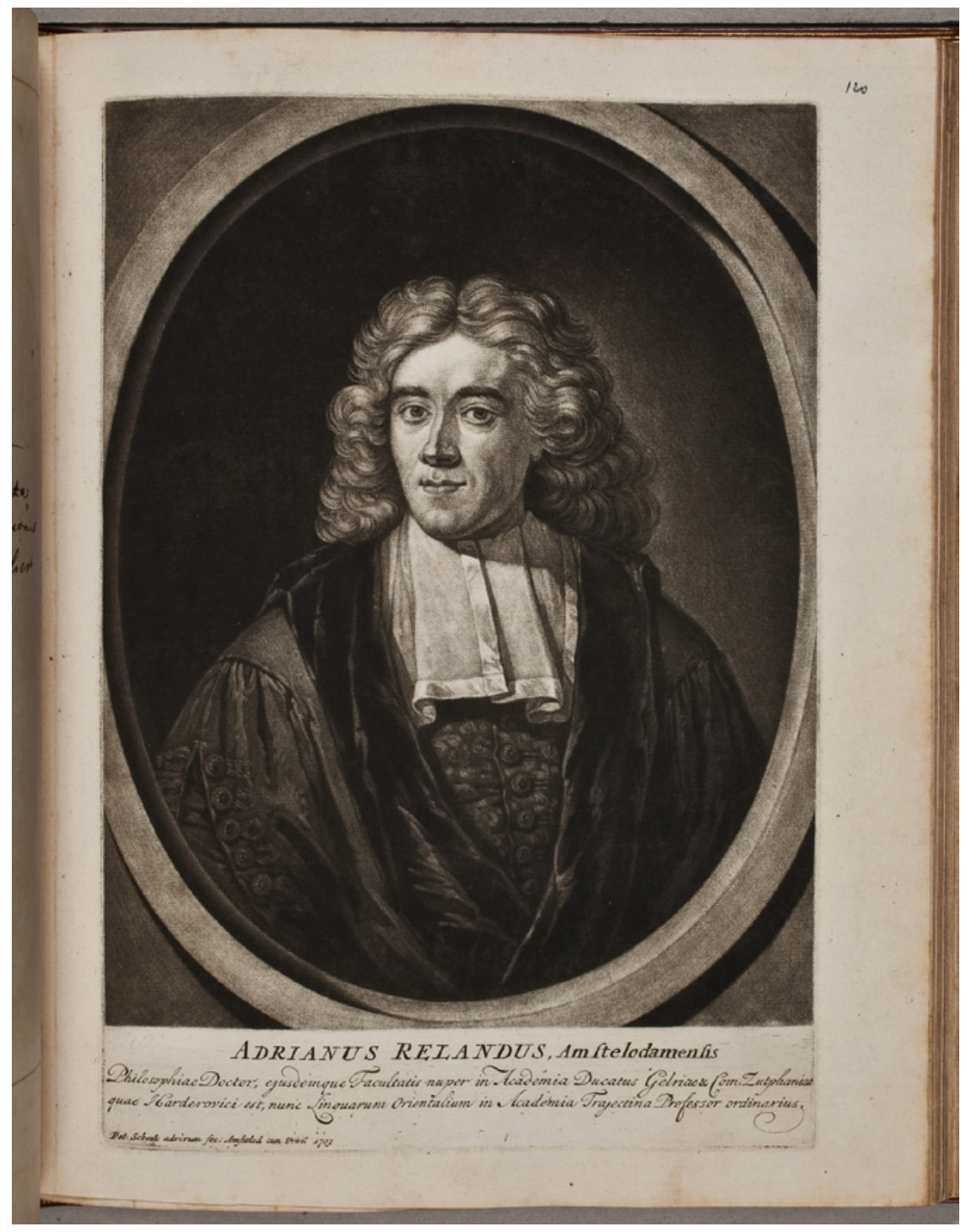


Rare accounts, like the one from Uffenbach's visit, provide us with a glimpse of the kind of person Reland was, and how he interacted with other people. Even though it is inherently difficult to extract intimate details from dusty archival material, the scattered fragments that usually get ignored in historical research, like the books he owned, objects he collected, letters he sent or received, interests he shared, and private notes he made, when pieced together, start to bring into focus aspects of Reland's personal life that have hitherto remained concealed from view. They reveal an avid experimental scientist who wrote poems about physics and played with Cartesian devils; a protégé of famous collectors who owned, amongst other things, a piece of ancient rubble of Persepolis and coins from the whole of East Asia; an armchair traveller who drew maps of Palestine, Japan and Persia; a son of a Reformed minister who defended Islam and happily dined with reputedly lewd and uncouth friends; a university professor and rector who interviewed an African slave to write a grammar of his language. For one man, who never left his home country, Reland seems to have possessed the gravitational pull that attracted a whole universe of exotic objects, undeciphered manuscripts, ground-breaking ideas, and inspiring people.

Further research is still required on topics like Reland's influence on his students; ${ }^{104}$ his correspondence with Cuper and other important cultural figures of the time requires a proper edition; his contacts with the Dutch East India officials and clergy, among others François Valentijn, may shed some light on Reland's attitude to the Orient. But the greater hope is that more letters, more archival fragments will emerge, that will complete the puzzle of Reland the man.

Yet the principles that guided Reland's life are best summarised in the epitaph he wrote for himself: 105

cette douceur, qui se trouvoient réllement dans son caractére, avec toute la prudence \& le sens rassis, qui peuvent préserver un honnête homme de brouilleries \& des querelles, qu'il est si difficile d'éviter dans le Commerce de la Vie Civile, \& surtout dans la République des Lettres. Il a toujours vécu paisiblement avec ses Collégues, qui lui ont accordé sans peine leur estime \& leur amitié. Jamais il n’a parlé ni écrit avec aigreur, contre ceux dont it combattoit les sentiments, \& sans se rendre coupable de la derniére férocité, on ne pouvoit pas devenir l'ennemi d'un Antagoniste si poli \& si honnête'; see Journal littéraire de l'année M.DCC.XVII, pp. 215-216.

104 For an exploratory survey of his student Schultens' teaching of Hebrew antiquities, with remarks on its relation to Reland's Antiquitates sacrae veterum Hebraeorum and on the latter's use of August Pfeiffer's classification of Hebrew antiquities as a structuring model see Eskhult, Albert Schultens as Teacher and Innovator of Comparative Hebrew Language Studies, (forthcoming). Also, cf. Ulrich Groetsch's chapter in this volume.

105 Serrurier, Oratio funebris, p. 46. 
Terra tegi cineres, quae cunas praebuit olim. Principium cursus, metaque facta mei.

Quisquis es, incertae stadium decurtere vitae

Dum licet, ante oculos meta sit usque tuos.

Conficitur spatium dispar, verum exitus omnes

Unus, \& hac hora te quoque forte manet.

Ergo vive Deo, praepone aeterna caducis,

Atque animi potior sit tibi cura tui.

Quidquid agis, paterisve tuis Christi exprime mores.

Non alis fas est, scandere ad astra via. ${ }^{106}$

\section{Bibliography}

\section{Sources}

Baldaeus, P., A True and Exact Description of the Most Celebrated East-India Coasts of Malabar and Coromandel and Also of the Isle of Ceylon ... Translated From The High-Dutch, London, A. Churchill, 1703 [1672].

Bentley, R., The Correspondence of Richard Bentley, D.D., C. Wordsworth (ed.), London, Murray, 1842.

Burmann, P., Le gazettier menteur, ou Mr. Le Clerc convaincu de mensonge de et calomnie, Utrecht, Willem vande Water, 1710.

Chauffepié, J.G. de, Nouveau dictionnaire historique et critique: pour servir de supplément ou de continuation au dictionnaire de Pierre Bayle, Amsterdam, Chatelain et al., 1756.

Epictetus, The Discourses as Reported by Arrian, the Manual and Fragments, translated by W.A. Oldfather, Cambridge, MA, Harvard University Press, London, W. Heinemann Ltd., 1956 [1925].

Glanius, W., A New Voyage to the East-Indies: Containing an Account of Several of Those Rich Countries and More Particularly of the Kingdom of Bantam. London, H. Rodes, 1682.

106 'The earth covers the ashes of the deceased; once upon a time, it supplied the cradle, the beginning of my journey; and now the destination has been reached.

Whoever you are as you move ahead on the uncertain course of life, you should always keep the (final) destination in your eyes.

An uncertain course is completed, but the end is one and the same for everybody, and this hour remains firm for you as well.

Thus, lead a life for God, choose the eternal rather than the fleeting, and make the care for your soul a priority.

Whatever you do or whatever you attain, model the conduct of Christ to your own; nothing but divine law is the road that leads to heaven [to the stars]'. (Translation Ulrich Groetsch). 
Journal littéraire de l'année M.DCC.XVII, vol. 10, The Hague, T. Johnson, 1718, pp. 211-222. Kate, Lambert ten, Gemeenschap tussen de Gottische spraeke en de Nederduytsche, I. van de Bilt and J. Noordegraaf (eds), Amsterdam and Münster, Stichting Neerlandistiek vu and Nodus Publikationen, 2001.

Leeuwen, G., and J. Luyts, Exercitatio physica de vacuo ... sub prcesidio M. Joannis Luyts, Utrecht, François Halma, 1696.

Leibniz, G.W. Collectanea etymologica, vol. 2, Hannover, Foerster, 1717.

Lucan [Marcus Annaeus Lucanus], The civil war, trans. J.D. Duff, Loeb Classical Library no. 220, Cambridge, MA, Harvard University Press, 1928.

Luyts, J., Introductio ad geographiam novam et veterem: in qua necessaria hujus scienttiae prolegomena ... Adjiciuntur suis locis Oceani, Terrae et cujusque regionis tabulae, item Cartae LXV Sansonis ..., Utrecht, François Halma, 1692.

Memoirs of Literature: Containing a Large Account of Many Valuable Books, Letters and Dissertations Upon Several Subjects, Miscellaneous Observations, Etc., vol. 3, 2nd edn., London, R. Knaplock and P. Vaillant, 1722.

Naam-lyst van een zeer keurige verzameling ... boeken ... [\&] Catalogus codicum manuscriptorum Arabicorum ..., Utrecht, Willem Kroon and Gijsbert Tieme van Paddenburg, 1761.

Proces, geventileert voor den Ed. Gerechte van Utrecht, tusschen den heer ende mr. Petrus Burmannus, professor in de Academie alhier, in cas van injurien contra den heer Daniel Voet, medicinae doctor, Rotterdam, P. de Vries, 1711.

Reland, A., Brieven van Adriaan Reland (1676-1718) aan Engelbertus Van Engelen (?-1684), [unpublished letters], 1715, Leiden, University Library, PAP 15.

Reland, A., 'De vacuo', The Hague, Royal Library, 121 E 5.

Reland, A., Dissertatio altera De inscriptione nummorum quorundam Samaritanorum, ad spectatissimum virum, Jacobum de Wilde ... Utrecht, T. Appels, 1704.

Reland, A., Dissertatio De inscriptione nummorum quorundam Samaritanorum, vol. 1. Amsterdam, François Halma, 1702.

Reland, A., Dissertationum miscellanearum pars tertia et ultima, Utrecht, Willem Broedelet, 1708.

Reland, A., Lettre à son excellence monseigneur le comte de Kniphuisen, ambassadeur \& plenipotentiaire de messieurs les Etats de Groningue \& d'Omlanden pour la paix d'Utrecht. Sur une pièce d'or trouvée dans ses terres, Utrecht, n.p., 1713.

Reland, A., [unpublished letter to R. Leers], 28 March 1706, Leiden, University Library, BPL 426.

Reland, A., [unpublished letters to N. Witsen], in 'Brieven van Nicolaas Witsen aan G. Cuper', 1714, Amsterdam, University Library, Hs. Bf 82b.

Reland, A. and J. Luyts, Exercitationis physico-mathematica De umbra pars prior, Utrecht, François Halma, 1694. 
Rochefoucauld, F. La, Maximes et réflexions morales, ed. by Louis Lacour, Paris, Académie des Bibliophiles, 1868 [1678].

Ruëll, J., Grammatica of Singalëse taal-kunst, zijnde een korte methode om de voornaamste fondamenten van de Singalese spraak te leren, Amsterdam, François Halma, 1708.

Schouten, W., Oost-Indische voyagie; vervattende veel voorname voorvallen en ongemeene vreemde geschiedenissen [...], Amsterdam, J. van Meurs and J. van Someren, 1676.

Serrurier, J., Oratio funebris in obitum viri celeberrimi Hadriani Relandi, antiquitatum sacrarum et linguarum orientalium professoris ordinarii, recitata ipsis nonis Martiis MDCCXVIII, Utrecht, Willem vande Water, 1718.

Sike, H., Evangelium infantiae, vel Liber apocryphus de infantia Servatoris ... Utrecht, François Halma and Willem vande Water, 1697.

Uffenbach, Z.K. von, Merkwürdige Reisen durch Niedersachsen Holland und Engelland: Dritter Theil, Ulm, Gaumischen Handlung, 1754.

Valentijn, F., Oud en nieuw Oost-Indiën: vervattende een naaukeurige en uitvoerige verhandelinge van Nederlands mogentheyd in die gewesten ..., 5 vols, Dordrecht and Amsterdam, Joannes van Braam and Gerard onder de Linden, 1724-1726.

Verwer, A. Brief aen den Heere Adriaen Reland, professor der Oostersche talen in de Academie tot Utregt, vanden Schryver der Linguae Belgicae Idea Grammatica; \&c. tot rekenschap vande Aenmerkingen vanden Heer Arnold Moonen op dezelve Idea; en van 't richtig Nederduitsch, zoo als door onze Hooge Overheidt gebruikt is in Hare nieuwe overzetting des Bybels, Utrecht, Willem Broedelet, 1709.

\section{Studies}

'Alba amicorum: the original Facebook for Renaissance teens?', The Guardian, 5 Dec 2018, https://www.theguardian.com/books/2018/dec/05/british-library-alba -amicorum-renaissance-facebook (accessed 18 January 2020)

Anderson, D., Lens on Leeuwenhoek [website], https://lensonleeuwenhoek.net/content/estate-maria-van-leeuwenhoek (accessed 22 September 2019).

Ansorge, C., 'From Andalusia to Cambridge' [web blog], Cambridge University Library Special Collections, 19 October 2015, https://specialcollections-blog.lib.cam .ac.uk/?p=10956 (accessed 1o September 2019).

Bergvelt, E., D.J. Meijers and M. Rijnders (eds), Kabinetten, galerijen en musea. Het verzamelen en presenteren van naturalia en kunst van 1500 tot heden, Zwolle, 2005.

Bruyn, C. de, Reizen over Moskovie. Een Hollandse schilder ontmoet tsaar Peter de Grote, ed. K. Hannema, Amsterdam, Stichting Terra Incognita, 1996.

Berkowitz, C., 'Pumped Up' [web blog], in Distillations. Using Stories from Science's Past to Understand our World, Science History Institute, 17 July 2014, https://www .sciencehistory.org/distillations/article/pumped-up (accessed 12 October 2019). 
Chen, B., 'Digging for Antiquities with Diplomats: Gisbert Cuper (1644-1716) and his Social Capital', Republics of Letters: A Journal for the Study of Knowledge, Politics and the Arts, vol. 1, no. 1, 2009, http://rofl.stanford.edu/node/36.

Clercq, P.R. de, At the Sign of the Oriental Lamp: The Musschenbroek Workshop in Leiden, 1660-1750, Rotterdam, Erasmus, 1997.

Delft, M. van, 'Over de knie in Rusland' [web blog], 28 September 2012, The Hague, Royal Library, https://www.kb.nl/blogs/boekgeschiedenis/over-de-knie-in-rusland (accessed 22 September 2019).

Eskhult, J., Albert Schultens as Teacher and Innovator of Comparative Hebrew Language Studies, History of Oriental studies, Leiden, Brill, forthcoming.

Floor, W., 'Abbāsì', in K. Fleet et al. (eds), Encyclopaedia of Islam, THREE, Leiden and Boston, Brill, http://dx.doi.org/10.1163/1573-3912_ei3_COM_23237 (accessed 1 February 2O2O).

Forrer, K., 'Dutch Academic Theses and Printed Matter', in W.A. Kelly and G. Trentacosti (eds), The Book in the Low Countries, Edinburgh, Merchiston Publishing, 2015, pp. $55^{-79}$.

Forster, L. 'Henry Sike of Bremen (1669-1712) Regius Professor of Hebrew and Fellow of Trinity', Transactions of the Cambridge Bibliographical Society, vol. 10, no. 3, 1993, pp. 249-27, online: www.jstor.org/stable/41154824.

Gnirrep, K., 'Een experimentele kleurendruk', in G. Jurriaans-Helle (ed.), Cornelis de Bruijn. Voyages from Rome to Jerusalem and from Moscow to Batavia, Amsterdam, Allard Pierson Museum, 1998, pp. 6o-61.

Groetsch, U., 'The Scholar as Whoremonger. Petrus Burman (1668-1741) and the Dark Abysses of Classical Scholarship', in M. Mulsow (ed.), Kriminelle-FreidenkerAlchemisten. Räume des Untergrunds in der Frühen Neuzeit, Cologne, Weimar and Vienna, Böhlau, 2014, pp. 557-574.

Hamilton, A. 'Sike, Henry (bap. 1669, d. 1712), Orientalist', Oxford Dictionary of National Biography, 2004, https://www.oxforddnb.com/view/10.1093/ ref:odnb/978o198614128.oo1.ooo1/odnb-9780198614128-e-72828 (accessed 12 February 2020).

Jurriaans-Helle, G. (ed.), Cornelis de Bruijn. Voyages from Rome to Jerusalem and from Moscow to Batavia, Allard Pierson Museum, Amsterdam, 1998.

Kuiper, K., 'The Earliest Monument of Dutch Sinological Studies', Quaerendo, vol. 35, no. 1, 2005, pp. 109-139.

Lankhorst, O., Reinier Leers (1654-1714), uitgever \& boekverkoper te Rotterdam: een Europees 'libraire' en zijn fonds avec un résumé en français, Amsterdam, APA-Holland Universiteits Pers, 1983.

Matthee, R., Persia in Crisis: Safavid Decline and the Fall of Isfahan, London, I.B. Tauris, 2012. 
Mitchell, F., 'Khoisan Identity', South African History Online, https://www.sahistory.org. za/article/khoisan-identity (accessed 4 February 2020).

Noordegraaf, J., 'From "Radical Enlightenment" to Comparative Historical Linguistics. The Study of Language in the Netherlands around 1700', in G. Hassler and G. Volkman (eds), The History of Linguistics in Texts and Contexts.- Geschichte der Sprachwissenschaft in Texten und Konzepten. 2 vols, Münster, Nodus Publikationen, 2004, pp. 155-168.

Peters, M., 'Nicolaes Witsen and Gijsbert Cuper. Two Seventeenth-Century Burgomasters and their Gordian Knot', Lias, vol. 16, no. 1, 1989, pp. 111-151.

Roemer, B. van de, 'Neat Nature: The Relation between Nature and Art in a Dutch Cabinet of Curiosities from the Early Eighteenth Century', History of Science, vol. 42, 2004, pp. 47-84.

Schmidt, B., Inventing Exoticism: Geography, Globalism, and Europe's Early Modern World, Philadelphia, University of Pennsylvania Press, 2015.

Suid-Afrikaanse argiefstukke: Kaap, vol. 4, Cape Town, Government Printer, 1962.

Van Noord, W. and T. Weststeijn (2015), 'The Global Trajectory of Nicolaes Witsen's Chinese Mirror', The Rijksmuseum Bulletin, vol. 63, no. 4, 2015, pp. 325-361.

Winnerling, T., 'A Ghost Network' [web blog], The Fading of Remembrance Project, https://fading18-2o.hypotheses.org/823, (accessed 16 September 2019).

Zuidervaart, H.J., 'Cabinets for Experimental Philosophy in the Netherlands', in J.A. Bennett and S. Talas (eds), Cabinets of Experimental Philosophy in EighteenthCentury Europe, Leiden, Brill, 2013.

Zuidervaart, H.J., 'The "Invisible Technician" Made Visible: Telescope Making in the Seventeenth and Early Eighteenth-Century Dutch Republic', in A.D. Morrison-Low et al. (eds), From Earth-Bound to Satellite, Leiden, Brill, 2012, pp. 41-102.

Zuwiyya, Z., 'Juan Andrés', in D. Thomas (ed.), Christian-Muslim Relations 15001900, a Bibliographical History Online, Leiden and Boston, Brill, http://dx.doi .org/10.1163/2451-9537_cmrii_COM_24646 (accessed 1 February 2O2O). 